\title{
Active lakes of Recovery Ice Stream, East Antarctica: a bedrock-controlled subglacial hydrological system
}

\author{
Helen Amanda FRICKER, ${ }^{1}$ Sasha P. CARTER, ${ }^{1}$ Robin E. BELL, ${ }^{2}$ Ted SCAMBOS ${ }^{3}$ \\ ${ }^{1}$ Institute of Geophysics and Planetary Physics, Scripps Institution of Oceanography, University of California, San Diego, \\ La Jolla, CA, USA \\ E-mail: hafricker@gmail.com \\ ${ }^{2}$ Lamont-Doherty Earth Observatory, Columbia University, Palisades, NY, USA \\ ${ }^{3}$ National Snow and Ice Data Center, University of Colorado at Boulder, Boulder, CO, USA
}

\begin{abstract}
A connected system of active subglacial lakes was revealed beneath Recovery Ice Stream, East Antarctica, by ICESat laser altimetry. Here we combine repeat-track analysis of ICESat (2003-09), Operation IceBridge laser altimetry and radio-echo sounding (2011 and 2012), and MODIS image differencing (2009-2011) to learn more about the lake activity history, the surface and bedrock topographic setting of the lakes and the constraints on water flow through the system. We extend the lake activity time series to 2012 for the three lower lakes and capture two major lake drainages. One lake underwent a large deflation between 2009 and 2011 while another lake, which had been continuously filling between 2003 and 2010, started to drain after 2011. Most of the active lakes are located in a $\sim 1000 \mathrm{~km}$ long bedrock trough under the main trunk of Recovery Ice Stream, whose base is $\sim 1500$ $2000 \mathrm{~m}$ below present-day sea level. The hydrologic system beneath Recovery Ice Stream is controlled by this unusually pronounced bedrock topography, in contrast to most Antarctic systems studied to date, which are controlled by the ice surface topography. Hydrologic connections among the lakes appear to be direct and responsive, and we reproduce the lake activity using a simple subglacial water model. We discuss potential causes of non-steady hydrologic behavior in major Antarctic catchments.
\end{abstract}

KEYWORDS: Antarctic glaciology, remote sensing, subglacial lakes

\section{INTRODUCTION}

The realization nearly a decade ago that subglacial lake activity causes ice surface elevation changes that are detectable by satellite altimetry (Gray and others, 2005; Wingham and others, 2006; Fricker and others, 2007) has transformed our understanding of the Antarctic ice sheet's subglacial water system. Prior to this discovery the major components of the subglacial hydrologic system were thought to be isolated stable lakes located primarily near ice divides (e.g. Siegert and others, 2005) and quasi-steady distributed water flow beneath the ice streams and outlet glaciers (Engelhardt and Kamb, 1997). We now understand that the hydrologic system is connected throughout (Wright and others, 2012), with water travelling distances of hundreds of $\mathrm{km}$ in broad but well-defined channels on timescales of a few months (Wingham and others, 2006; Carter and others, 2009a; Flament and others, 2014). Water flow continues to the grounding line, providing a pathway for subglacial water to reach the Southern Ocean (Goodwin, 1988; Fricker and others, 2007; Carter and Fricker, 2012; Le Brocq and others, 2013) and contribute directly to sea-level rise. Glacier flow changes, especially glacier changes that strongly affect ice surface slope, can 'activate' subglacial water bodies and cause a drainage event (Scambos and others, 2011). The presence of water beneath an ice stream, and its action as a lubricant either between the ice and subglacial bed or between grains of a subglacial till, affects ice flow rates and thus continental ice flux (Kamb, 1987). Basal water systems may also serve to transport significant amounts of heat at the ice-sheet base (Parizek and others, 2003; Wolovick and others, 2013). Understanding these systems is therefore crucial for ice-sheet modelling.
Surface deformation resulting from subglacial lake activity leads to anomalously large $\left(>1 \mathrm{~m} \mathrm{a}^{-1}\right)$ localized elevation changes: elevation gain over filling lakes (positive $\mathrm{d} h / \mathrm{d} t$ ), and elevation loss (negative $\mathrm{d} h / \mathrm{d} t$ ) over draining lakes; such signals have now been detected by several satellite instruments. The first demonstration of this used RADARSAT synthetic aperture radar data on Kamb Ice Stream, West Antarctica, over a single time interval (Gray and others, 2005). Satellite-radar-altimeter derived $\mathrm{d} h / \mathrm{d} t$ estimates for a longer time period (1995-2003) at four altimeter crossovers were attributed to linked draining and filling of subglacial lakes near Adventure Trench, East Antarctica (Wingham and others, 2006). Repeat-track analysis of Ice, Cloud and land Elevation Satellite (ICESat) laser altimetry for the period 2003-06 identified a complex, active plumbing system involving linked reservoirs under the fast-flowing portions of three large West Antarctic ice streams (Whillans, Mercer and MacAyeal), and the $\mathrm{d} h / \mathrm{d} t$ signals combined with areas from MODIS image differencing allowed for estimates of volume changes (Fricker and others, 2007, 2010; Fricker and Scambos, 2009). A continent-wide study by Smith and others (2009) used automated processing of ICESat data from 2003 to 2008 to produce an inventory of 124 lakes undergoing detectable $\mathrm{d} h / \mathrm{d} t$ ('active' lakes), at locations different from those mapped with previous methods (e.g. Siegert and others, 2005; Wright and Siegert, 2012); ten active lakes were identified in the Recovery catchment.

Recovery Ice Stream (previously called 'Recovery Glacier' (Swithinbank and others, 1988)) is Antarctica's longest dynamic ice-flow feature, extending $\sim 1000 \mathrm{~km}$ into the interior of the East Antarctic ice sheet (Jezek and others, 2003; Rignot and others, 2011). It drains a large area of 


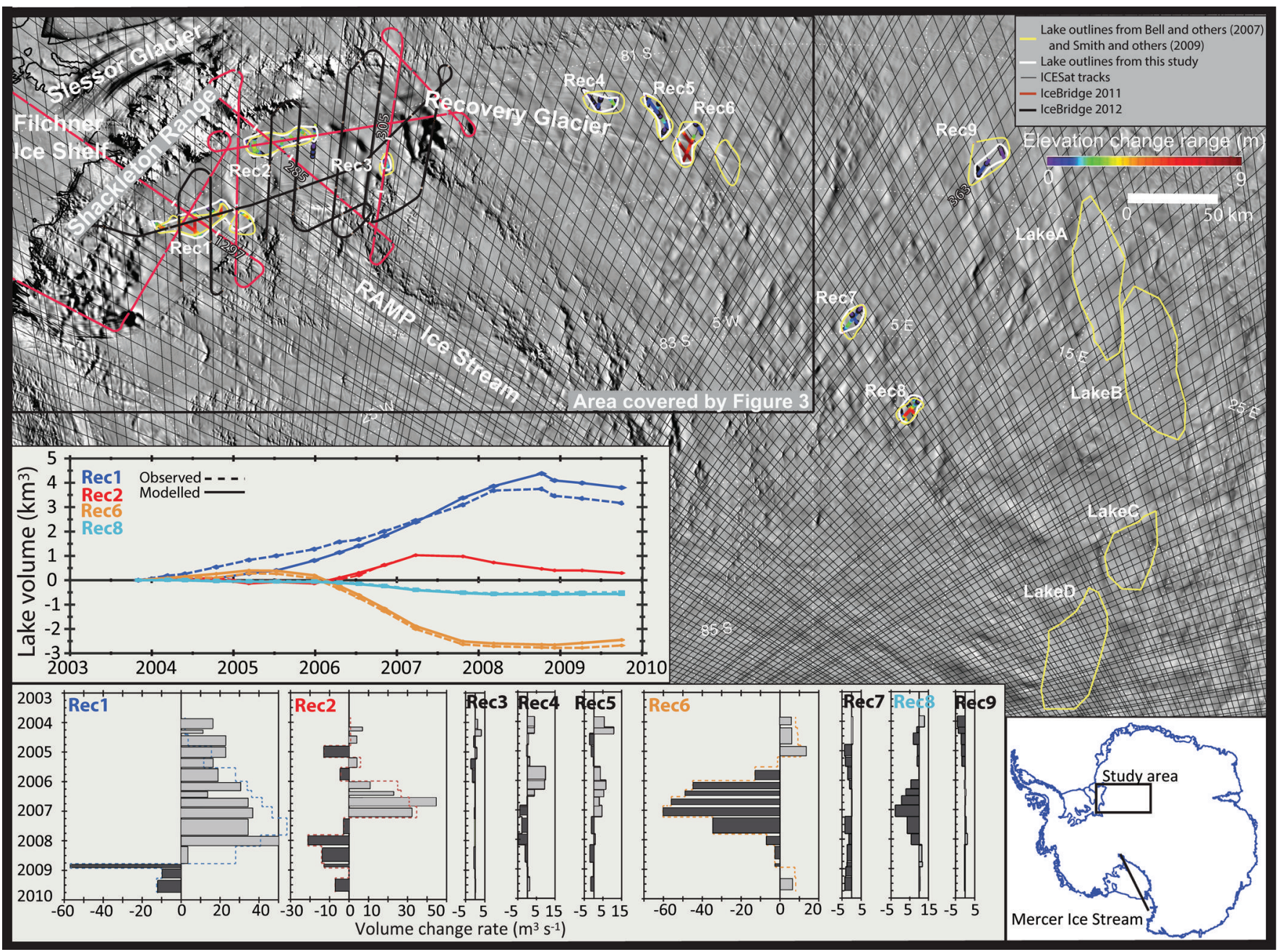

Fig. 1. Main panel: MODIS Mosaic of Antarctica (MOA) over Recovery Ice Stream showing all known active and static lakes in the system, including Bell and others (2007) lakes and Smith and others (2009) lakes and the locations of active subglacial lakes found in this study. ICESat reference tracks are shown as black thin lines with coloured line segments over lakes representing the total range of elevation during the ICESat period (2003-09); colour scale at top right. IceBridge flight lines for 2011 and 2012 are shown. The 2011 flights were F07 on 21 October 2011 , which included ICESat track 404 across Rec2, and F16 on 7 November 2011 which flew along ICESat tracks 1297 and 97 (Rec1), 285 (Rec2), 305 (Rec3). The 2012 flight was on 18 October 2012, which included ICESat tracks 112 and 350 (Rec1), 335 and 82 (Rec2), 1302,181 and 171. The segments where we compared Airborne Topographic Mapper (ATM) with ICESat data are labeled with the track number; the white ticks indicate the $50 \mathrm{~km}$ line segments shown in Figure 5. Upper inset left: volume change time series for the four main active Recovery Ice Stream lakes: ICESat observations 2003-09 (solid lines) and modelled time series (dashed lines). Lower inset left: water volume flux through the nine lakes of the active subglacial lake system over the ICESat period 2003-09; dark grey is water loss (flooding) and light grey is water gain (filling) at each lake. Lower inset right: study location in Antarctica.

Dronning Maud Land, equivalent to $8 \%$ of the entire Antarctic ice sheet area, and provides $58 \%$ of the ice flux into the Filchner Ice Shelf (Joughin and Bamber, 2005; Joughin and others, 2006). The Smith and others (2009) active lake inventory described ten active lakes under the main trunk of the lower Recovery Ice Stream and resolved the movement of subglacial water through this system for the period 2003-08 (see Fig. 1 for lake locations). Farther upstream, four large lakes were identified close to the Recovery Ice Stream onset area of fast flow, using both traverse and satellite data (Bell and others, 2007; see Fig. 1 for lake locations). Aligned along a tectonic boundary and characterized by extensive very low-slope areas of the ice sheet, it is thought that these lakes are stable and are likely at a low stand (e.g. Langley and others, 2011). Recovery Ice Stream is far from major research bases, and field expeditions have been limited to geologic exploration of the Shackleton Mountains (e.g. Faure and Mensing, 2010), one seismic and gravity traverse during the 1957 International Geophysical Year, and a US/Norwegian traverse over the upper lake system during the International Polar Year (IPY) 2008-09. The AGAP (Anarctica's Gamburtsev Province) project (Bell and others, 2011) flew three exploratory flights over the two southern large lakes during the IPY (Langley and others, 2014). NASA's Operation IceBridge mission flew six flights in the Recovery region in October and November 2011 and November 2012 (see Fig. 1 for flight lines).

In this study we combine repeat-track ICESat laser altimetry data (2003-09), IceBridge laser altimetry and radio-echo sounding (RES; 2011 and 2012) and MODIS image differencing (2009-11) to show the activity of the Recovery Ice Stream lake system from 2003 to 2012 and describe the topographic setting for these active lakes. We corroborate the extent of the subglacial drainage using an image-differencing method (Bindschadler and others, 2010). We also estimate the hydropotential controlling the water 
flow and describe general constraints on the flow of water through the system. Using a subglacial water model, we simulate basal water distribution and subglacial lake filling rates, to test the consistency between the catchments and flow paths implied by our hydropotential surface and inferred lake volume change.

\section{DATA}

\subsection{ICESat}

ICESat carried the first laser altimeter to be flown in a nearpolar orbit, and operated between October 2003 and November 2009 in a 91 day repeat orbit $\left(86.0^{\circ} \mathrm{S}\right.$ to $86.0^{\circ} \mathrm{N}$ ) with a 33 day sub-cycle. ICESat carried three lasers, and, due to laser lifetime concerns following the failure of the first laser, most of the mission was operated in a 'campaign mode', whereby the last 33 days of the first Laser 2 campaign (called 'Laser 2a campaign', which spanned 44 days total) were repeated, providing 17 repeats of the same 33 day subcycle. ICESat acquired laser altimetry spot elevations at a $40 \mathrm{~Hz}$ rate, or every $\sim 172 \mathrm{~m}$ along-track, with a footprint diameter of $50-70 \mathrm{~m}$. We used Release 633 of the data, the most current at the time of writing (see http://nsidc.org/data/ icesat/data_releases.html\#rel33 for details). We applied the saturation correction from the GLA12 product. We used a simple gain filter to remove data that are affected by clouds, generally removing all data with a gain value higher than 50 . In 2013, Borsa and others (2014) reported a range error in the ICESat data, known as the Gaussian centroid (GC) offset. Since the amplitude of the GC offset is much smaller than the signal we are looking at, however, we did not make this correction for this analysis.

\subsection{MODIS}

Two imaging sensors, Moderate Resolution Imaging Spectroradiometers (MODIS), fly on NASA's Terra and Aqua multi-sensor satellite platforms, launched in 2000 and 2003 respectively. The MODIS sensor acquires image data in 32 bands, each with 10-bit radiometric resolution. MODIS image swaths are wide $(\sim 2400 \mathrm{~km})$ and the satellites complete 14 orbits daily. In the polar regions, the image swaths overlap significantly, providing several images per day under a range of solar illumination (in summer). MODIS data have been used to create cloud-cleared mosaics of the ice sheet, in 2003/04 and 2008/09 (MODIS Mosaic of Antarctica (MOA); Scambos and others (2007) describe the earlier compilation in detail).

\subsection{IceBridge}

NASA's Operation IceBridge is an airborne mission designed to fill the gap between NASA's two laser altimeter satellites: ICESat (2003-09) and its follow-on, ICESat-2, to be launched in 2017. The mission has operated annually in Antarctica since 2009, and is planned to run until at least a year after the ICESat-2 launch. IceBridge flew six flight lines with the NASA DC-8 aircraft over Recovery Ice Stream, which included several ICESat tracks across the three lower Recovery lakes; three tracks were repeated in 2011 and four in 2012 (Fig. 1).

We used two different IceBridge datasets to study the Recovery lakes system. We used elevation data from the Airborne Topographic Mapper (ATM) laser altimeter (Krabill, 2014) to determine lake activity since the end of the ICESat mission. We also used IceBridge ice thickness data profiles, derived from radar images acquired by the
MCoRDS (Multichannel Coherent Radar Depth Sounder Level 2) (Allen, 2010) combined with the Bedmap2 ice thickness database (Fretwell and others, 2013), to map the basal (bedrock) topography and provide a hydropotential surface for our water budget model.

\section{METHODS}

\subsection{Lake activity from ICESat repeat-track analysis}

We analysed ICESat data following the repeat-track technique described by Fricker and others $(2007,2010)$ and Fricker and Scambos (2009). For each lake, we derive an average elevation for the entire lake at epochs that correspond to the centre of each ICESat campaign, in the following steps:

1. Calculated the elevation anomaly for each repeat (the difference of the elevation profile acquired during each campaign from the mean of all repeat profiles) for every track across each lake. We improved on the repeat-track technique used in previous studies (e.g. Fricker and Scambosk 2009) by splitting the $\sim 275 \mathrm{~m}$ wide swath of repeat tracks into narrower strips of tracks that repeat more closely (100-200 m), to reduce noise introduced by cross-track slope error (see Fig. 2).

2. Estimated the average anomaly for each repeat track to provide an elevation for each epoch for each track, referenced to the elevation at the first epoch.

3. For each epoch, we averaged the elevations from all tracks, using a weighted-average scheme described in Fricker and others (2010), where weights are equal to the length of the 'on-lake' track segment divided by the sum of all on-lake track segment lengths present in that epoch, to provide a single, lake-averaged elevation.

The resulting lake-averaged time series for each lake is the average of the elevation anomaly along each track, averaged over all tracks sampled during a campaign. We plotted the elevation anomalies on MOA and estimated the lake areas from these. The volume time series were obtained by multiplying the elevation time series by the estimated lake areas, assuming that the lake area remains constant at all stages of a lake fill-drain cycle.

\subsection{MOA lake outlines and MODIS image differencing}

The MOA composite image was used along with ICESat elevation change information to estimate the lake boundary for several of the lakes. MOA provides a very accurate image of the surface topography illuminated from a single general direction (solar azimuth at 0600-1200 UTC over the entire continent). From this a surface depression slope feature can often be identified that bounds the extent of the ICESat elevation change areas. A trace of this feature is used as a first approximation of the probable subglacial lake extent.

To confirm the full spatial extent of an elevation change anomaly between the ICESat tracks, and the sign and magnitude of changes seen by the ICESat and IceBridge altimeter data, we use satellite image differencing. This involves subtraction of two similarly illuminated satellitederived images spanning the period of interest (technique described by Fricker and others, 2007; Fricker and Scambos, 2009; Bindschadler and others, 2010). For this study, we generated difference images for two lakes (Rec3 and Rec1) 


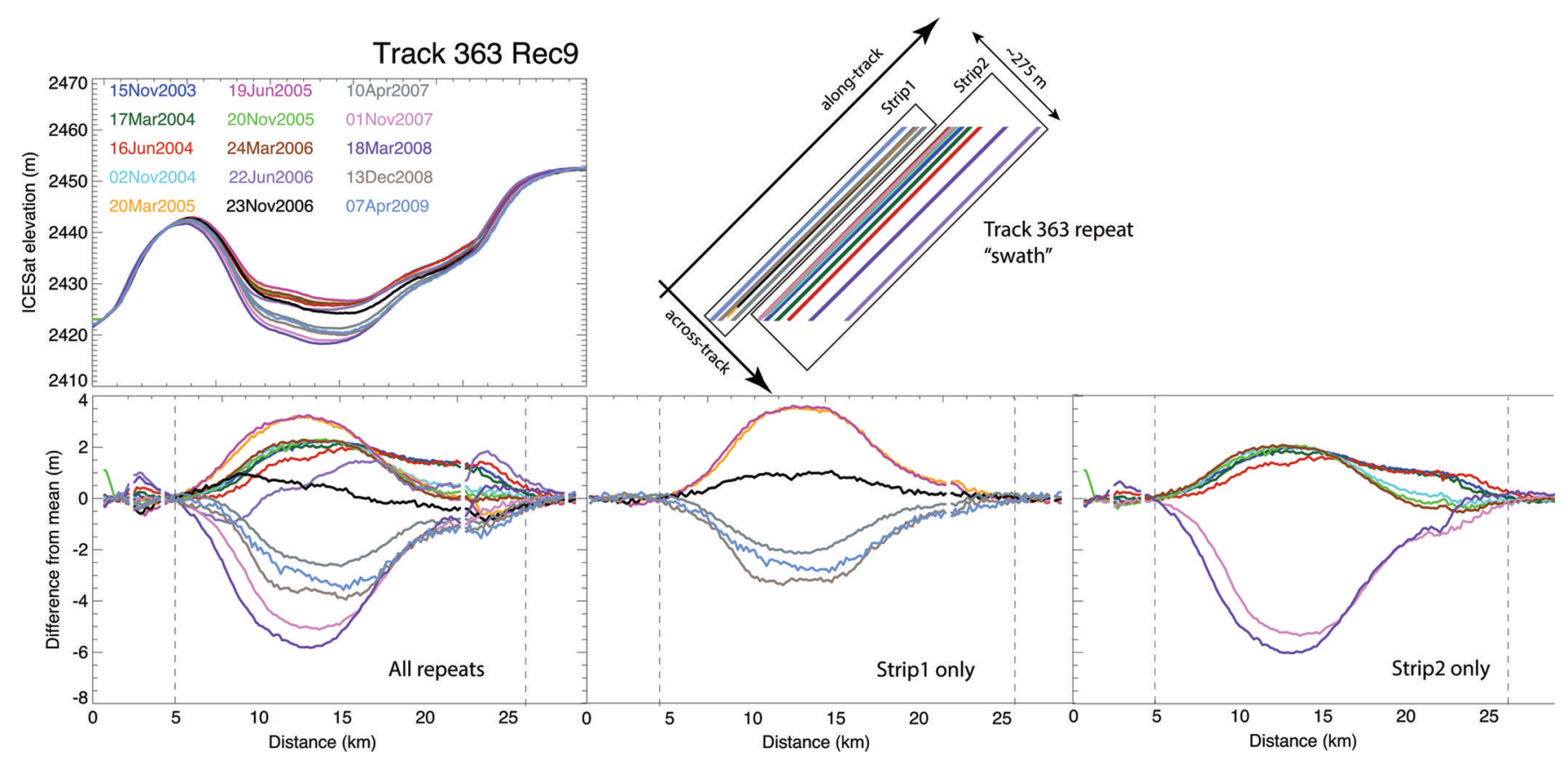

Fig. 2. Improved ICESat analysis to reduce the effect of cross-track topography on 'swath' of repeat tracks for track 363 across Rec9 (see Fig. 1 for location). We improved on the repeat track technique by splitting the $275 \mathrm{~m}$ wide swath of repeat tracks into narrower strips of tracks that repeat closely (generally $100-200 \mathrm{~m}$ ) to reduce the effect of (unknown) cross-track topography on the elevation anomaly, and treating them as independent tracks. In regions of rough topography, this technique improves the signal to noise ratio for those tracks whose 'swaths' of repeats are broad.

from subtraction of two image averages, acquired in 2008 and 2011 for Rec3 and 2009 and 2011 for Rec1, using band 1 (red light: Bindschadler and others, 2010). The image averages (i.e. the pixel-by-pixel average value of a co-located 'stack' of overlapping satellite images) were composed of two to about five MODIS scenes acquired within a relatively short period of time ( $\sim 6$ weeks). All images were acquired under near-identical solar illumination conditions. Differencing of the image averages separated by (in this case) 3 years produced an image of sunward slope change over the image difference interval. Two different image average sets, and image differences, were produced with image sets acquired under different solar azimuths. The two different images, produced with image sets of different illumination direction, served as a check on our results.

\subsection{Lake activity from IceBridge laser altimetry}

The ICESat tracks that cross the three lowermost lakes (Rec1, Rec2 and Rec3) were flown by IceBridge in 2011 and 2012, providing snapshots of lake volume change. We compared the IceBridge data (2011 and 2012) with the 2009 ICESat elevations to construct a post-ICESat time series. For each ICESat track that was flown by IceBridge, we extracted the surface elevation across the lake from the ATM data, using the nadir beam only, and compared it with the ICESat elevation data.

\subsection{Hydropotential from IceBridge radar ice thicknesses and Bedmap2}

We used the IceBridge MCoRDS along with the Bedmap2 database (Fretwell and others, 2013) to construct a hydropotential surface following the Shreve (1972) formulation:

$$
\phi=z_{\mathrm{b}}+\frac{\rho_{\mathrm{i}}}{\rho_{\mathrm{w}}} h_{\mathrm{i}}
$$

where $\rho_{\mathrm{w}}$ and $\rho_{\mathrm{i}}$ are the densities of water $\left(1000 \mathrm{~kg} \mathrm{~m}^{-3}\right)$ and ice $\left(917 \mathrm{~kg} \mathrm{~m}^{-3}\right)$, respectively, $z_{\mathrm{b}}$ is the measured elevation of the ice base and $h_{\mathrm{i}}$ is the ice thickness (equal to $z_{\mathrm{s}}-z_{\mathrm{b}}$, with $z_{\mathrm{S}}$ being the measured elevation of the ice surface). Given this equation for governing basal pressure gradients of a thin liquid layer, surface elevation gradients are 11 times more significant than bed gradients for determining the direction of basal water flow. Bedrock gradients however, can locally exceed surface gradients by a factor of $>11$.

Although Bedmap2 represents the best bedrock map of Antarctica to date and has successfully assimilated a great variety of data sources including all IceBridge ice thickness and bedrock elevations from 2011 and earlier, a substantial degree of smoothing was applied to the input dataset for the Recovery Ice Stream region. In particular, features in the basal topography that would be important to our understanding of the flow of water in this region may have not been resolved. To take advantage of the high resolution of the IceBridge bed topography in places where it is available, we make the bed elevation of any $2.5 \mathrm{~km} \times 2.5 \mathrm{~km}$ gridcell containing IceBridge measurements equal the average of all samples within it, and the bed elevation of points more than $7.5 \mathrm{~km}$ ( $\sim 3$ gridcells) distant from an IceBridge measurement equal to the Bedmap2 value. We then fit a two-dimensional bi-cubic spline to the region within $7.5 \mathrm{~km}$ of an IceBridge measurement, but not actually covered by IceBridge to preserve smoothness. The initial hydropotential was then obtained using Eqn (1) and the Bedmap2 surface elevation. We made further improvements to the hydropotential grid through 'etching' and 'tuning'; both are described in detail in Appendix A.

\subsection{Modelling water flux over the ICESat period 2003-09}

Previous modelling work suggests that in catchments where subglacial lakes exist, lakes capture nearly all the meltwater inflow from upstream (Carter and others, 2011; Carter and 
Fricker, 2012). This makes it possible to infer water routing and connectivity through a hydrologic system if there are concurrent observations of volume change for all lakes in the system.

We used the subglacial water model of Carter and others (2011) and Carter and Fricker (2012) to simulate basal water distribution and subglacial lake filling rates in Recovery Ice Stream and the hydrologic catchment that supplies it, and to test the consistency between the catchments and flow paths implied by our hydropotential surface and inferred lake volume change.

The water model (described in Appendix B) requires three inputs: (1) a basal melt rate to produce water for the system; (2) a time series of lake volume change to control the water supply and compare to model output; and (3) a hydropotential grid to determine where water is routed. For (1), we experimented with melt rates of both 0.7 and $1.0 \mathrm{~mm} \mathrm{a}^{-1}$ over the entire Recovery catchment (as a reasonable orderof-magnitude approximation in both modelling (e.g. Evatt and others, 2006) and observational (e.g. Carter and others, 2009b; Siegert and others, 2014) work on large catchments in Antarctica). For (2) we used our ICESat time series. We created (3) following Appendix B, using an ice thickness grid combined with a digital elevation model.

\section{RESULTS}

The combination of ICESat, IceBridge data and image differencing provided significant new information about the Recovery Ice Stream lakes, including the bedrock topography beneath them and how it controls the transport of water through the system. We present the bedrock topography results first (Section 4.1), describe the lake activity for the ICESat and IceBridge periods (Section 4.2) and then present the modelling results (Section 4.3).

\subsection{Bedrock topography controls on Recovery subglacial hydrology}

\subsubsection{Bedrock topography and ice velocity}

The gridded bedrock map from the IceBridge/Bedmap2 ice thickness data shows the basal morphology of Recovery Ice Stream (Fig. 3a). An elongated bedrock trough underlies the central trunk of Recovery Ice Stream. The ice stream is bisected into upper and lower troughs by a 500-1000 m high ridge located at $\sim 17^{\circ} \mathrm{W}$; the $500 \mathrm{~km}$ long lower segment is up to $2000 \mathrm{~m}$ deep and $40 \mathrm{~km}$ wide. Bounded by the Shackleton Range to its north, the lower trough has steep lateral margins (typical slope of 0.2-0.6), where total bedrock relief from the top of the Shackleton Range to the bottom of the Recovery trough approaches $4000 \mathrm{~m}$. The upper segment is $\sim 1500 \mathrm{~m}$ shallower and slightly wider. Ice thickness is 2500-3000 m over the lower trough and 3000$3500 \mathrm{~m}$ in the upper trough. The high velocities in the main Recovery Ice Stream trunk are generally confined to the deep troughs (Scheuchl and others, 2012; Fig. 3b).

Downstream of the main trunk a broad ridge, presumed to be a southern extension of Shackleton Range, rises at least $1000 \mathrm{~m}$ to its crest $(-200 \mathrm{~m}$ to $-700 \mathrm{~m})$ (Fig. 3a). Close to the eastern edge of the Shackleton Range, as the lower trough rises towards the grounding line, the ice flow bifurcates (Fig. 3b; see also Figs $3 \mathrm{c}$ and 4). The western portion of the ice flow moves towards a narrow section of grounding line, widely accepted to be the Recovery Ice Stream grounding line. The eastern portion of the ice flow veers to the east up a

Ice-base elevation (m)

$\begin{array}{lllllllllll}-2000 & -1800 & -1600 & -1400 & -1200 & -1000 & -800 & -600 & -400 & -200 & 0\end{array}$
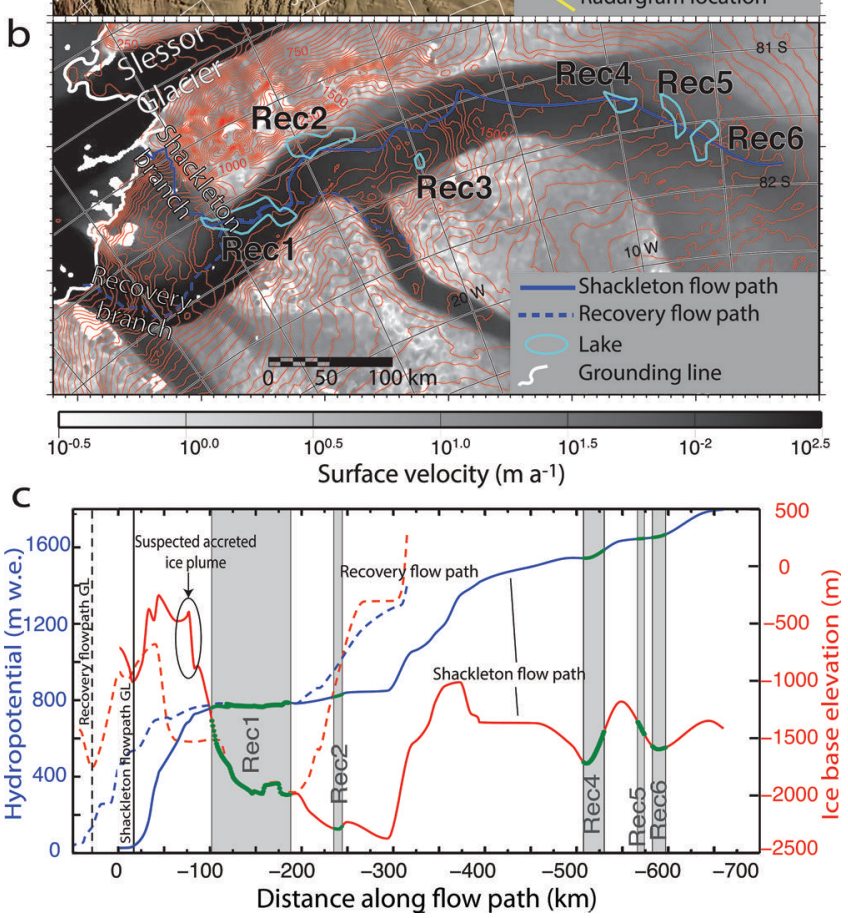

Fig. 3. (a) Map of ice-base elevation for main trunk of Recovery Ice Stream derived from IceBridge ice thickness data and Bedmap2. (b) Ice surface velocity (from Scheuchl and others, 2012) with contours of hydropotential. In (a, b), the three IceBridge flight segments corresponding to the radargrams shown in Figure 5 are marked as yellow lines $A-A^{\prime}, B-B^{\prime}, C-C^{\prime}$. The primary hydrologic flow path (solid line) leaves Rec1 and passes over a saddle in the Shackleton Range (Shackleton branch); secondary flowline follows the ice flow direction (Recovery branch). (c) Hydropotential and bed elevation along the primary flow path (solid lines) and secondary flow path (dashed lines). The primary flow path (Shackleton) has less of a hydropotential barrier than the path that follows the ice flow. Ice-base elevation map shows that Recovery Ice Stream is grounded in a trough. Location of suspected 'freezeon' of basal ice (see Fig. 4) is indicated.

and over the elevated topography at the edge of the Shackleton Range. This ice goes afloat adjacent to the Slessor Glacier inflow. We refer to the southern limb as the 'Recovery branch' and the northern limb as the 'Shackleton branch' (Fig. 3b and c).

The grounding line is located on the downstream side of the ridge, $>500 \mathrm{~m}$ below the crest; the grounding line depth is $1700 \mathrm{~m}$ at the location of maximum ice flux (Recovery branch) and $1000 \mathrm{~m}$ at our inferred location of subglacial discharge (Shackleton branch; Fig. 3a-c). This suggests that at present Recovery Ice Stream is mostly grounded on a prograde slope, with the deeper southern section occupying a local minimum in a trough; this trough is probably 

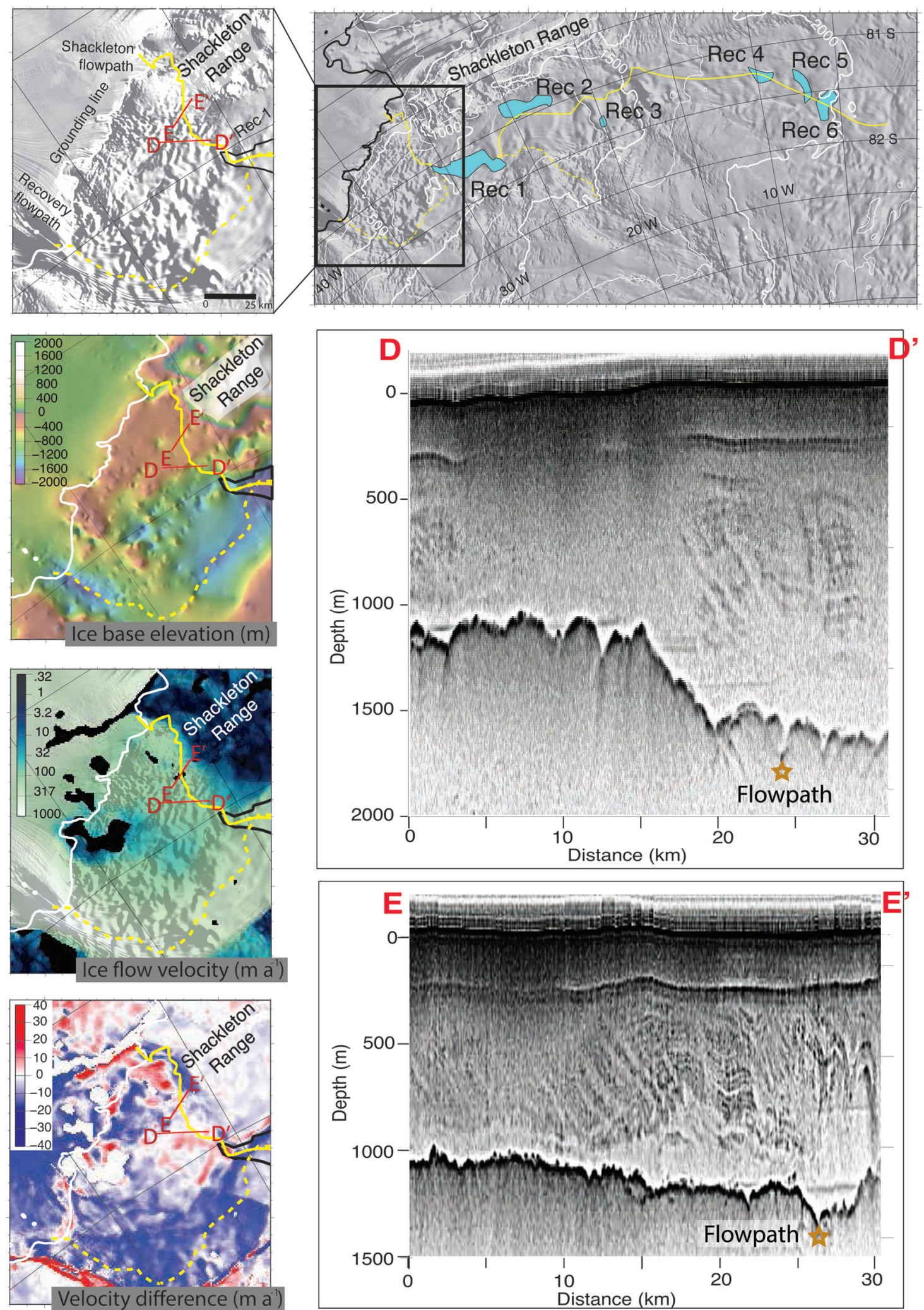

Fig. 4. Flow bifurcation region downstream of Rec1. Top right is a location map showing lakes, hydrologic flow paths, and contours of ice surface elevation (interval $250 \mathrm{~m}$; note steepening of ice surface near grounding line); rectangle shows the area covered by left panels. Left panels (from top to bottom): MOA showing the locations of the two predicted hydrologic flow paths (Shackleton flow path and the Recovery flow path; dashed and solid yellow lines), the location of segments D-D' and E-E' of IceBridge flight on 29 October 2011, and the grounding line; ice-base topography highlighting bedrock ridge crossed by the Shackleton flow path (solid yellow line); ice surface velocity (Rignot and others, 2011); and ice surface velocity difference between 2009 and 1997 (Scheuchl and others, 2012). The panels at middle and bottom right are radargrams acquired by IceBridge radar along segments $\mathrm{D}-\mathrm{D}^{\prime}$ and $\mathrm{E}-\mathrm{E}^{\prime}$ (location shown on map figures). Middle: radargram oriented parallel to ice flow near suspected region of accreted ice, showing the stoss face of the Shackelton range and structural deformation in the overlying ice, related to ice flow. Bottom: radargram from the IceBridge radar along segment $\mathrm{E}-\mathrm{E}^{\prime}$, showing features that are not parallel to the bed that may indicate accretion of basal water formed as water travels up and over the saddle in the Shackleton Range and freezes into the ice-stream base. Note the closeness of the internal layers to the ice base on either side of the upwarping, and the absence of layering in the lower part of the upwarped region. 
Table 1. Statistics of the nine lakes in the Recovery system identified using 2003-09 ICESat data in this study, and the four lakes discovered by Bell and others (2007). Unless otherwise indicated, values were obtained from mean and standard deviation of all IceBridge measurements of ice thickness and surface elevation occurring within the lake boundary

\begin{tabular}{|c|c|c|c|c|c|}
\hline & $\begin{array}{l}\text { Area } \\
\mathrm{km}^{2}\end{array}$ & $\begin{array}{l}\text { Elevation (WGS84) } \\
\text { m }\end{array}$ & $\begin{array}{l}\text { Ice thickness } \\
\text { m }\end{array}$ & $\begin{array}{l}\text { Hydropotential } \\
\text { mw.e. }\end{array}$ & $\begin{array}{c}\text { Ice-base elevation } \\
\mathrm{m}\end{array}$ \\
\hline \multicolumn{6}{|c|}{ Lake name } \\
\hline Rec1 & 1005 & $995 \pm 13$ & $2821 \pm 172$ & $779 \pm 11$ & $-1806 \pm 165$ \\
\hline $\operatorname{Rec} 2 *$ & 681 & $1105 \pm 1$ & $3397 \pm 2$ & $822 \pm 3$ & $-2191 \pm 2$ \\
\hline $\operatorname{Rec} 3$ & 60 & $1279 \pm 3$ & $2973 \pm 95$ & $1032 \pm 10$ & $-1704 \pm 92$ \\
\hline $\operatorname{Rec} 4$ & 220 & $1847 \pm 8$ & $3481 \pm 52$ & $1558 \pm 6$ & $-1640 \pm 45$ \\
\hline $\operatorname{Rec} 5$ & 273 & $1947 \pm 1$ & $3371 \pm 46$ & $1658 \pm 3$ & $-1531 \pm 45$ \\
\hline Rec6 & 394 & $1974 \pm 17$ & $3371 \pm 261$ & $1695 \pm 28$ & $-1384 \pm 264$ \\
\hline $\operatorname{Rec} 7^{+}$ & 227 & $2332 \pm 9$ & $2765 \pm 72$ & $2103 \pm 8$ & $-434 \pm 67$ \\
\hline $\operatorname{Rec} 8^{+}$ & 225 & $2453 \pm 181$ & $2594 \pm 181$ & $2237 \pm 16$ & $-141 \pm 176$ \\
\hline $\operatorname{Rec} 9^{+}$ & 283 & $2450 \pm 5$ & $3263 \pm 90$ & $2179 \pm 5$ & $-950 \pm 86$ \\
\hline Lake A* & 2914 & $2403 \pm 53$ & $3340 \pm 245$ & $2125 \pm 33$ & $-930 \pm 192$ \\
\hline Lake B* & 1586 & $2318 \pm 13$ & $3397 \pm 151$ & $2036 \pm 12$ & $-1078 \pm 144$ \\
\hline Lake $C^{+}$ & 3930 & $2635 \pm 6$ & $3260 \pm 195$ & $2363 \pm 14$ & $-625 \pm 196$ \\
\hline Lake D* & 3155 & $2408 \pm 15$ & $3146 \pm 148$ & $2147 \pm 20$ & $-738 \pm 149$ \\
\hline
\end{tabular}

*Values obtained from $<10$ points. For lakes A, B and D, we used seismically derived ice thicknesses from the Bedmap2 ice surface (Fretwell and others, 2013).

${ }^{\dagger}$ Ice thickness and surface elevation values obtained from Bedmap2 (Fretwell and others, 2013).

connected to the larger Crary Trough that lies beneath much of Filchner Ice Shelf. In contrast, Slessor Glacier to the north has a retrograde slope over $\sim 100 \mathrm{~km}$ of its length, from the Crary Trough into a similarly deep lower-glacier trough, with no topographic barrier (Fig. 3).

\subsubsection{Location of active subglacial lakes}

We identified nine active subglacial lakes in the Recovery system through our ICESat repeat-track analysis (Fig. 1; Table 1). Following the Smith and others (2009) convention, we named the lakes numerically starting from the most downstream lake and moving upstream (so the lake they called $R_{n}$, we call Recn). Two of the bodies that Smith and others (2009) identified as separate lakes (their $R_{1}$ and $R_{2}$ ), we found to be acting as a single larger lake (Rec1). Over one of the lakes (their $R_{7}$ ) identified by Smith and others (2009) we detected no signal in the surface elevation change above the noise (we use $0.5 \mathrm{~m}$ as the noise threshold); therefore, our lakes are named Rec1 to Rec9. These subglacial lakes are located at the base of the deep bedrock trough (Fig. 3a), and most are located towards its edges. Of the lower six lakes within the region covered by IceBridge, three (Rec6, Rec5 and Rec4) are in the upper trough above the steep bedrock ridge and three $(\operatorname{Rec} 3, \operatorname{Rec} 2$ and $\operatorname{Rec} 1)$ are in the lower, deeper trough.

\subsubsection{Hydropotential and subglacial water flow paths} Along the steep-sided trough in which Recovery Ice Stream sits, the hydropotential is predominately controlled by the bedrock topography (Fig. 3a and b). The lower six subglacial lakes are connected in a continuous chain, approximately following the ice-flow direction. Just downstream of the largest of the active lakes (Rec1), the primary hydrologic flow path diverges from the ice flowlines. This bifurcation in the hydrologic flow path is similar to the ice flow bifurcation (Figs $3 \mathrm{~b}$ and 4 ). In contrast to ice flow, the majority of the water flux flows over a $1500 \mathrm{~m}$ saddle in the Shackleton Range before discharging into the Filchner Ice Shelf cavity near Slessor Glacier, $>100 \mathrm{~km}$ north of where most ice discharge occurs. The ice stream crosses the southern extension of the Shackleton Range at its lowest topographic minimum. The steepening of the ice surface and the bifurcation in the subglacial water flow path both appear to be a consequence of the interaction between the ice flow and this southern subglacial extension of the Shackleton Range. Two radargrams acquired by the IceBridge radar in October 2011 show evidence of features not parallel to the bed, that may indicate accretion of basal water formed as water travels up and over the saddle in Shackleton Range and freezes into the ice-stream base (Fig. 4).

\subsection{Activity of Recovery Lakes}

There are various sources of uncertainty in the volume estimates derived from our combined ICESat repeat-track analysis and MODIS analysis: (1) the actual error in the ICESat averaged along-track measurement; (2) inadequate sampling of the lakes by the ICESat tracks; and (3) the error in the lake area. Previous studies have adopted percentage errors for their volume estimates (20\% (Fricker and others, 2010) and 50\% (Smith and others, 2009)); here we assign an uncertainty of $25 \%$ to each volume estimate.

\subsubsection{ICESat period 2003-09}

Our ICESat repeat-track analysis of elevation change enabled us to produce a volume time series for the nine active lakes (Rec1-Rec9; Fig. 1 inset). We discuss the elevation change, volume change and estimated water flux of the nine lakes, starting at the most upstream lake and moving down-glacier. We then compare the estimated water flux with the modelled water flux.

The most upstream active lake is Rec9, located $\sim 50 \mathrm{~km}$ downslope of the large lakes A and B. Our newly resolved area is $\sim 282 \mathrm{~km}^{2}$, which is substantially smaller than estimated by Smith and others (2009) $\left(\sim 728 \mathrm{~km}^{2}\right)$. Our altimetry-defined lake margin closely resembles the lake extent mapped by Langley and others (2011), using RES measurements of ice thickness and basal reflectivity. This suggests that lake shorelines determined using a combination 
of MODIS and ICESat (e.g. Fricker and others, 2007) are more precise and consistent with RES than those determined by laser altimetry alone (e.g. Smith and others, 2009). Our ICESat analysis showed that the surface of Rec9 subsided by $0.47 \mathrm{~m}$ between November 2003 and February 2006, which converts to $0.13 \mathrm{~km}^{3}$ of water at a maximum rate of $4 \mathrm{~m}^{3} \mathrm{~s}^{-1}$. Between then and the end of the observation period in 2009, Rec9 appears to have had no significant activity.

Lakes Rec8 $\left(\sim 225 \mathrm{~km}^{2}\right)$ and $\operatorname{Rec} 7\left(\sim 227 \mathrm{~km}^{2}\right)$ are located in the western branch of Recovery Ice Stream $\sim 100 \mathrm{~km}$ downslope of large lakes C and D. Both Rec8 and Rec7 were filling between November 2003 and March 2004 at rates of $2.9 \mathrm{~m}^{3} \mathrm{~s}^{-1}$ for Rec 8 and $0.6 \mathrm{~m}^{3} \mathrm{~s}^{-1}$ for Rec7. They began draining within 6 months of each other. Rec7 started draining first in March 2004, decreasing in elevation an average of $1.5 \mathrm{~m}$, consistent with a volume decrease of $0.33 \mathrm{~km}^{3}$ at an average rate of $2.1 \mathrm{~m}^{3} \mathrm{~s}^{-1}$ and peaking at $3.6 \mathrm{~m}^{3} \mathrm{~s}^{-1}$ between November 2004 and March 2005. Rec8 began draining in October 2004. The average elevation over the lake decreased by $2.4 \mathrm{~m}$ between March 2004 and March 2008, resulting in a volume loss of $0.57 \mathrm{~km}^{3}$ at an average rate of $4.6 \mathrm{~m}^{3} \mathrm{~s}^{-1}$, peaking at $12.6 \mathrm{~m}^{3} \mathrm{~s}^{-1}$ between October 2006 and March 2007. As the volume loss rate for Rec8 reached a maximum, volume loss for Rec7 temporarily halted. When drainage of Rec8 had ceased by March 2008, and filling began again at a rate of $0.6 \mathrm{~m}^{3} \mathrm{~s}^{-1}$ through the end of the ICESat observation period, $\operatorname{Rec} 7$ resumed draining at a rate of $3.1 \mathrm{~m}^{3} \mathrm{~s}^{-1}$. If the two lakes are connected, then input of water from Rec8 may have been enough to offset ongoing volume loss at Rec7 between March 2006 and March 2007. The lack of ice thickness data in this region, however, does not allow us to determine this conclusively.

Rec6 ( $394 \mathrm{~km}^{2}$ ) occupies one of the deeper parts of the upper Recovery trough. ICESat repeat-track analysis showed that the ice surface over Rec6 increased $0.7 \mathrm{~m}$ in the early portion of the ICESat record (November 2003 to March 2005); then from mid-2006 until the end of the mission in late 2009, the surface elevation decreased by a total of $7.8 \mathrm{~m}$. The increase in elevation from November 2003 to March 2005 could have resulted from an influx of water from Rec9, which was draining during this interval. Drainage of Rec6 began in March 2005, but outflow was initially fairly low, with most volume loss occurring between 2006 and 2009. The elevation decrease during this interval is equivalent to a drainage rate of $\sim 30 \mathrm{~m}^{3} \mathrm{~s}^{-1}$, and it peaked at $56 \mathrm{~m}^{3} \mathrm{~s}^{-1}$. The total volume lost from Rec6 during the ICESat observation period is $\sim 3 \mathrm{~km}^{3}$.

Downstream of Rec6 are two smaller lakes Rec4 $\left(220 \mathrm{~km}^{2}\right)$ and Rec5 $\left(273 \mathrm{~km}^{2}\right)$. Early in the ICESat observation period the elevation of the ice surface over each of these two lakes increased by 1.5 and $1.1 \mathrm{~m}$ respectively between 2003 and early 2007. The majority of uplift coincided with the drainage of Rec6. Together the two lakes increased in volume by $0.33 \mathrm{~km}^{3}$ at a rate of $6.3 \mathrm{~m}^{3} \mathrm{~s}^{-1}$. From early 2007 onward, the ice surface over these two lakes dropped, with Rec4 declining by $0.8 \mathrm{~m}$ and Rec5 declining by $0.3 \mathrm{~m}$, for a total volume loss of $0.2 \mathrm{~km}^{3}$, which represents a water outflow of $3.7 \mathrm{~m}^{3} \mathrm{~s}^{-1}$.

Three lakes are located downstream of the ridge that separates the upper and lower trough, one small (Rec3) and two large (Rec2 and Rec1). Rec3 is located along the western/southern margin of the ice stream, $30 \mathrm{~km}$ downstream of the ridge. This small $\left(60 \mathrm{~km}^{2}\right)$ lake was crossed by two ICESat tracks, which showed only a small
$(<1 \mathrm{~m})$ elevation decrease during the ICESat observation period. During this period the total range in observed elevation change is only $\sim 1.2 \mathrm{~m}$ averaged across the whole lake, with a maximum range of $2.4 \mathrm{~m}$ near the lake's center. The decrease in surface elevation over Rec3 indicates a minimum volume change of $0.07 \mathrm{~km}^{3}$ and a water flux of $0.57 \mathrm{~m}^{3} \mathrm{~s}^{-1}$.

The upstream large active lake $\left(\sim 681 \mathrm{~km}^{2}\right)$ is Rec2 located near the northern margin of the ice stream. Between November 2003 and November 2005, no significant elevation changes were detected by ICESat; then, between March 2006 and March 2007, the ice surface increased by a total elevation of $\sim 4 \mathrm{~m}$. This elevation increase requires a volume change of $1.0 \mathrm{~km}^{3}$ and an influx of water at $35 \mathrm{~m}^{3} \mathrm{~s}^{-1}$. The increase in Rec2 elevation is temporally coincident with the decreasing ice surface elevation of Rec6, and we interpret this as influx of water from Rec6. During the later part of the ICESat period, between March 2007 and November 2009, the ice surface over Rec2 dropped $1.1 \mathrm{~m}$, representing a volume change of $\sim 0.3 \mathrm{~km}^{3}$.

Rec1 is the largest active lake in the Recovery system $\left(\sim 1005 \mathrm{~km}^{2}\right)$, stretching the full width of the ice stream, and located close to where the basal hydrologic path and the ice flow bifurcate. ICESat observations show that the elevation of the lake increased throughout most of the mission; from the beginning of the mission until September 2008, the average elevation over Rec 1 increased by $\sim 0.76 \mathrm{~m} \mathrm{a}^{-1}$, with a resultant total elevation increase of $3.7 \mathrm{~m}$, representing a volume of $\sim 4.5 \mathrm{~km}^{3}$. From September 2008 through the end of the ICESat mission, elevation remained constant or decreased slightly, and the volume in November 2009 was $0.6 \mathrm{~km}^{3}$ below the September 2008 maximum. We interpret the associated total volume increase of $3.7 \mathrm{~km}^{3}$ over 5 years (2003-08) as ongoing filling of the lake (Fig. 1). The elevation change would require an influx of water at $24.1 \mathrm{~m}^{3} \mathrm{~s}^{-1}$ between 2006 and 2008, which is nearly twice the inflow between 2003 and 2006. The subsequent drainage discharged at a minimum of $18.8 \mathrm{~m}^{3} \mathrm{~s}^{-1}$ to points downstream.

Considering the active lake system as a whole, the observed elevation and volume changes indicate that most of the ICESat period (2003-08) was dominated by surface lowering over two mid-glacier lakes (Rec6 and Rec9) and surface inflation over the lower two lakes (Rec1 and Rec2; Fig. 1 inset). We interpret surface lowering at Rec9 as water loss via a flooding event that began before 2003; the water travelled 150-200 km downstream toward Rec6, which filled until 2005 and then began to drain. In 2006, 8-12 months later, the elevation increased over Rec2, which we interpret as infilling with subglacial water which travelled a distance of $\sim 350 \mathrm{~km}$ from Rec6. About 6 months later in 2006 the rate of ice surface inflation over Rec1 (another $\sim 50 \mathrm{~km}$ downstream) increased, which we also interpret as a response to the draining of Rec6. As Rec2 then began to drain in late 2007, the filling rate of Rec1 increased, until the onset of surface lowering of Rec1 in 2008. Since it is the lowest lake in the system before the grounding line, water from Rec1 flows presumably to the cavity under the Filchner Ice Shelf. We interpret this event as a cascading flood from Rec9 to Rec6, then to Rec2 and then to Rec1, and then to the ocean; a total distance of $\sim 800 \mathrm{~km}$. The last year of the ICESat period (2008-09) was characterized by little change in the upper lakes and small elevation changes over the lower two lakes, which we interpret as slow drainage. 


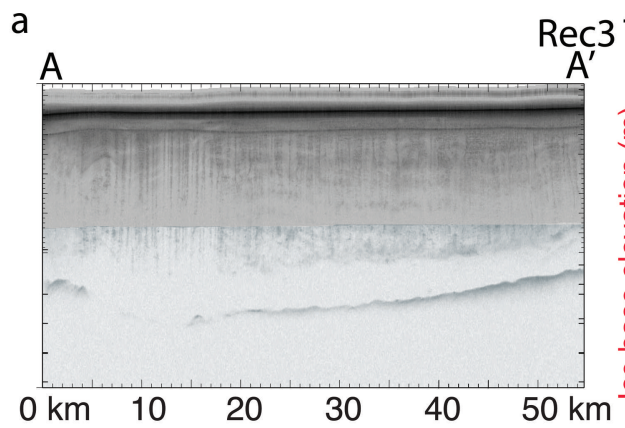

Rec3 Track 305
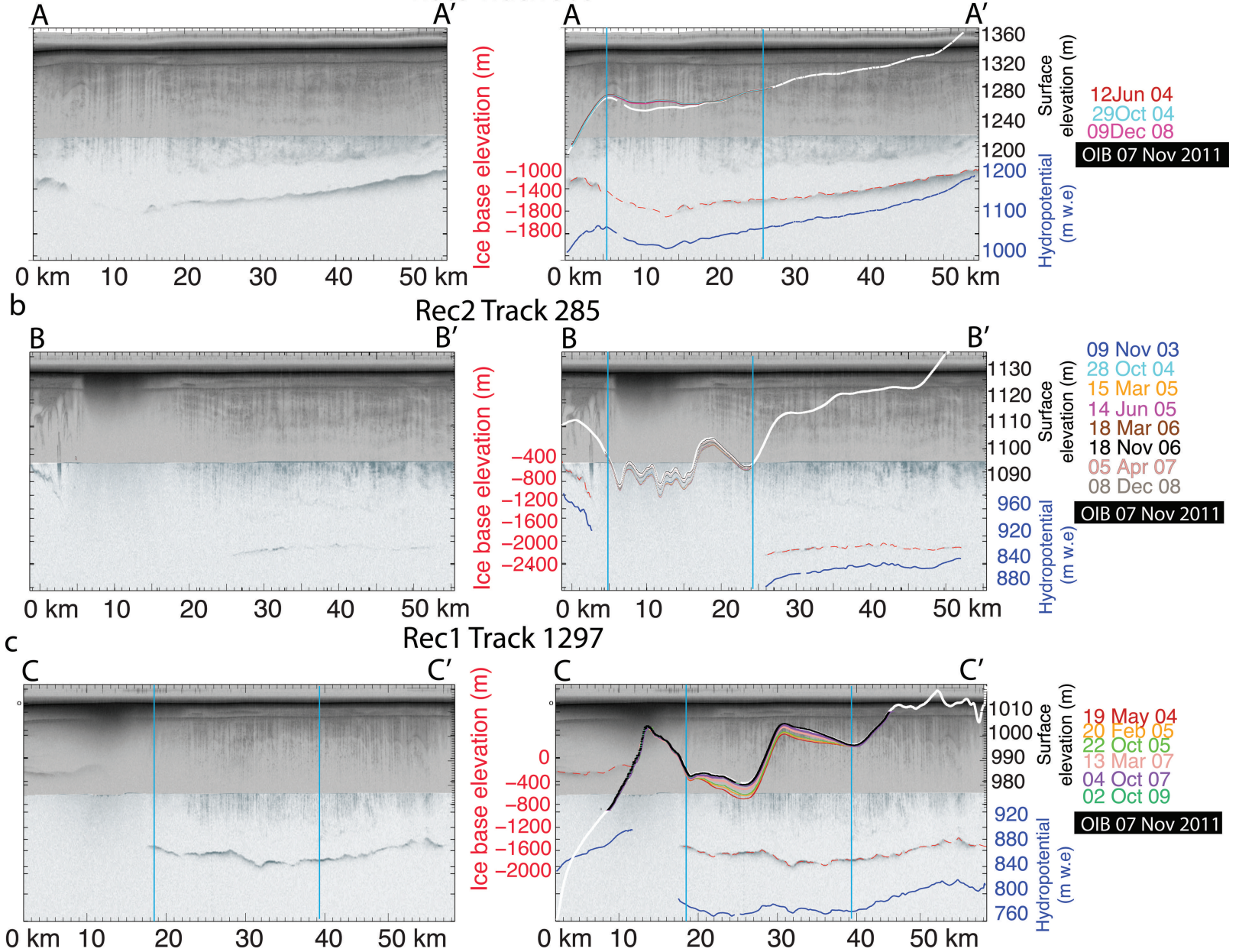

Rec2 Track 285

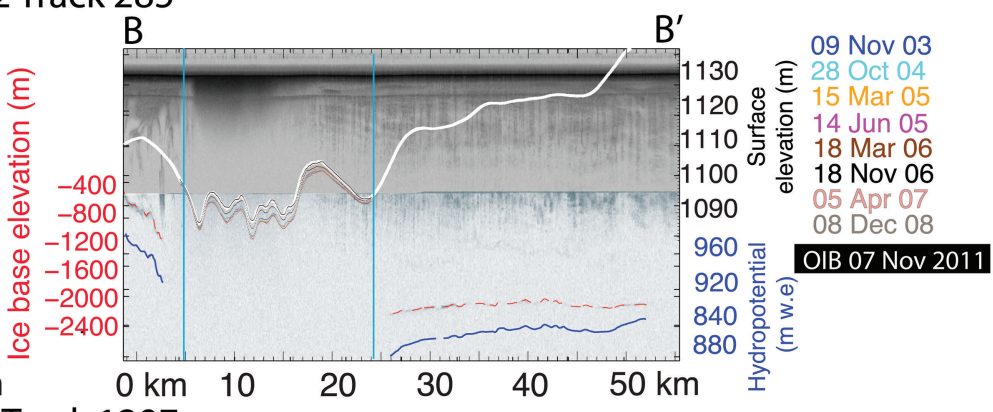

c1 Track 1297

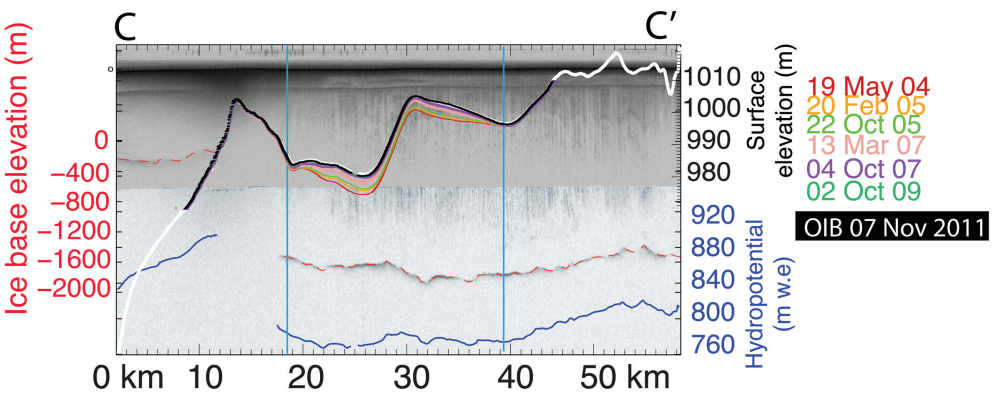

Fig. 5. IceBridge radargrams (unannotated at left) for three ICESat tracks that cross the lower three Recovery lakes: (a) track 305 Rec3; (b) track 285 Rec2; and (c) track 1297 Rec1. On each annotated radargram, the coloured lines towards the top are the surface elevation profiles from the ICESat repeats that were within $1 \mathrm{~km}$ of the IceBridge line (repeat dates at right in corresponding colours), and the white line is the IceBridge ATM surface elevation. The central line is the bed elevation picked from the radargram, and the bottom line is the hydropotential.

\subsubsection{Post-ICESat mission 2009-12}

The IceBridge lines provided new topographic information for the six lowest lakes in the Recovery Catchment (Rec1 to Rec6). The surveys covered $\sim 500 \mathrm{~km}$ of the $800 \mathrm{~km}$ long path that the cascading flood travelled along. The IceBridge altimetry data along ICESat tracks over Rec3, Rec2 and Rec1 enabled us to extend our record of changes in elevation and volume over the lakes in the lower trough, but the upper trough lakes (where the IceBridge lines were sparse and not parallel to earlier ICESat profiles) could not be extended.

In 2011, IceBridge overflew ICESat track 305 over Rec3. The IceBridge radar revealed a $400 \mathrm{~m}$ deep topographic low below the segment of the ICESat track that corresponds to Rec3 (Fig. 5a). Comparison of the ATM elevation profile with ICESat elevations indicated $\mathrm{a} \sim 10 \mathrm{~m}$ subsidence of the ice surface between 2009 and 2011 (Fig. 5a), across the same $\sim 10 \mathrm{~km}$ section where ICESat data revealed only small oscillatory elevation changes in 2003-09. This elevation change is of a similar magnitude to a change that occurred between 2003 and 2006 at Subglacial Lake Engelhardt, detected by ICESat and image differencing (Fricker and others, 2007). However, here it occurs over significantly thicker ice, making the inferred lake margin less sharp in both the difference image and the elevation profiles. MODIS image differencing between 2009 and 2011 (Fig. 6, right panels) shows evidence of surface elevation change in the same location, spanning a similar range to the ICESat vs IceBridgedefined region of elevation change, and yielding a difference structure compatible with the structure of the profile difference. The difference image is less distinct than the Subglacial Lake Engelhardt difference image (Fricker and others, 2007), however, because of the thicker (and colder, stiffer) ice.

Rec2 is located in a deep subglacial basin along the eastern margin of Recovery Ice Stream and is covered with thick $(\sim 3500 \mathrm{~m})$ ice (Fig. $5 \mathrm{~b})$. In this region, the trough bends, RAMP Ice Stream enters to the west and the ice stream is heavily crevassed. The combination of thick ice and heavy crevassing makes it a challenging radar environment, and the IceBridge RES instrument was unable to acquire a basal return over the lake (Fig. 5b).

IceBridge flew along ICESat tracks that cross Rec2 in both 2011 and 2012, overflying track 285 in November 2011 and tracks 335 and 82 in October 2012. Between 2008 and 2011 there was a $\sim 1 \mathrm{~m}$ uplift over Rec2 (track 285). In contrast, the comparison of the ICESat and IceBridge 2012 elevations (tracks 335 and 82) showed an elevation drop of $\sim 3 \mathrm{~m}$ relative to the mean 2011 elevation (Fig. 5b), which we interpret as a drainage event. This suggests that Rec2 reached its maximum volume between November 2011 and October 2012. 


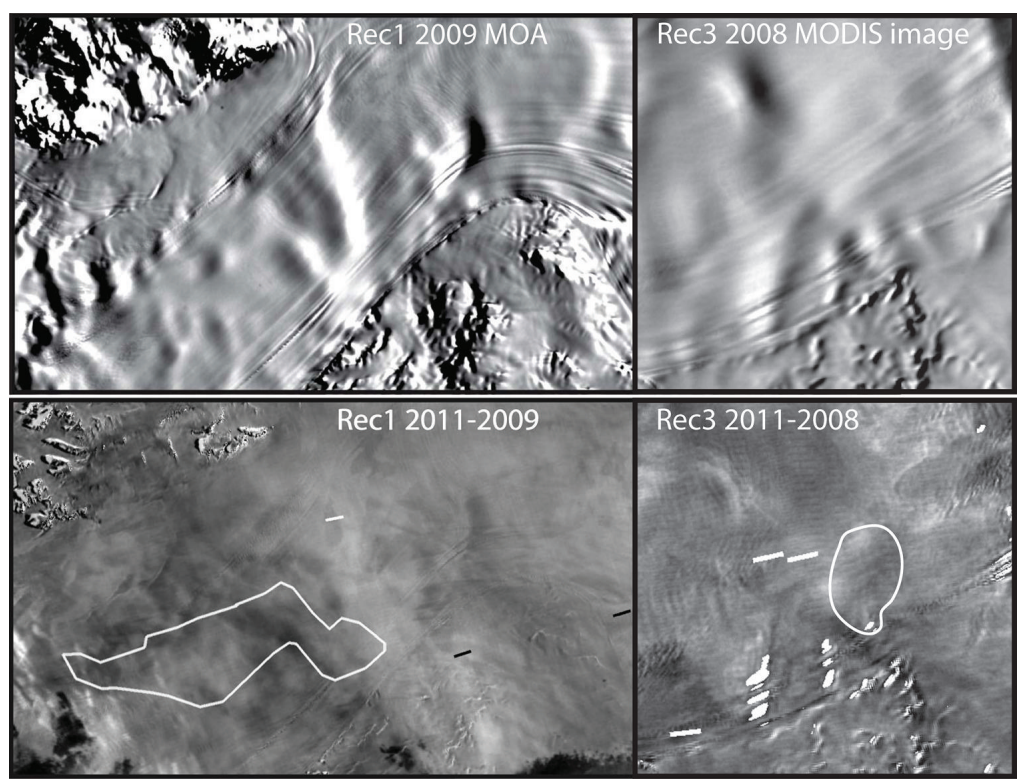

Fig. 6. MODIS images (top) and difference images (bottom) spanning the IceBridge and ICESat epochs for two lakes: Rec1 (left panels) and Rec3 (right panels). Top left: a sub-scene from the MOA2009 image mosaic (Haran and others, 2005). Bottom left: 2011-2009 MODIS difference image shows a smooth residual surface indicating no significant topographic changes in the lower glacier or over the lake outline. Top right: MODIS mosaic image of Rec3 subglacial lake area. Bottom right: 2011-2008 difference image shows a significant change in topography. Illumination of the images (and therefore of the residual representation of the change in the difference image) is from the right. The dark region on the right side of the Rec3 lake outline in its difference image, and bright patches on the left side, indicate changes in slope that are consistent with a multi-meter elevation loss at some time in the 2009-11 interval.

In contrast to Rec2 and Rec3, Rec1 extends diagonally over $70 \mathrm{~km}$ across the full width of the Recovery Trough. The IceBridge RES ice thickness data revealed that the ice here is thinner $(\sim 2500-2900 \mathrm{~m})$ and the trough is more symmetric. All three radar profiles crossing Rec1 have $2-3 \mathrm{~km}$ long segments of hydraulically flat bed that appears brighter and more consistently reflective than its surroundings, suggesting the presence of water (Wolovick and others, 2013). The RES data also revealed that a $300 \mathrm{~m}$ step in the ice-base topography coincided with the location of the maximum elevation anomaly from ICESat for the 2003-09 period (Fig. 5c) and a $\sim 30 \mathrm{~m}$ step in the surface topography of the opposite slope. Although the hydropotential along with the elevation change observations indicate that the ice is in flotation over the entire structure, the mechanism for creating and maintaining such a steep thickness gradient in floating ice is unclear.

Rec1 was surveyed by IceBridge both in 2011 and 2012, along five ICESat tracks (2011: tracks 112, 1297 and 97; 2012: 112, 335 and 350). When the November 2011 IceBridge altimetry data were compared with the October 2009 ICESat data, there was no detectable elevation change along the repeats of tracks 97 and 1297 (Fig. 5c). The absence of elevation change between October 2009 and November 2011 was confirmed by MODIS image differencing for the same period (Fig. 5, left panels). Similar to Rec2, a distinct elevation change was detected when the November 2012 IceBridge altimetry was compared with the November 2009 ICESat data: between ICESat observations in November 2009 and the first IceBridge overflight in October 2012 there was an elevation drop of $\sim 2 \mathrm{~m}$ (too small to detect with image differencing) along tracks 335 and 350. The elevation change between the two IceBridge observations indicates the lake started to drain between November 2011 and October 2012. The surface elevation in 2012 was still $\sim 5 \mathrm{~m}$ above the elevation observed at the start of the ICESat mission (October 2003). If the system was returning to its early ICESat state, then we infer that the drainage event was ongoing during the 2012 IceBridge survey.

\subsection{Modelled water flux over the ICESat period 2003-09}

We modelled the water fluxes necessary to reproduce the observed elevation changes during the 6 year ICESat period, with the goal of matching the observed filling rates of the two large lower lakes (Rec1 and Rec2). We used a relatively modest value for catchment-wide basal melt $\left(0.7 \mathrm{~mm} \mathrm{a}^{-1}\right)$, and allowed the large lakes (A-D) to be filling the entire time. Our water budget model predicted that the large upper lakes received $\sim 7.7 \mathrm{~m}^{3} \mathrm{~s}^{-1}, 46 \%$ of the total meltwater budget produced in the Recovery catchment (area $869 \mathrm{~km}^{2}$ ). At these inflow rates, surface uplift on these large lakes would be below the ICESat detection limit. Regional basal melt is sufficient to support the water flux through the active lakes without input from the large lakes upstream (Bell and others, 2007; Langley and others, 2011).

Our modelling was the most successful for the lower six lakes, where there are sufficient ice thickness data; lack of ice thickness data, necessary for determining flow routing, in areas of steep basal topography as has been observed elsewhere in our study area, limited the ability of our model to reproduce the filling rates of the upper three active lakes (Rec7, Rec8 and Rec9), where the ice and bed topography used was based primarily on a gravity model (Fretwell and others, 2013).

Our model suggests that volume is conserved during a cascading flood between lakes Rec9, Rec6, Rec2 and Rec1, with lakes Rec5, Rec4 and Rec3 acting as through-flowing features at this time. This suggests that Rec7 and Rec8 may be connected to one another; however, further interpretation is 


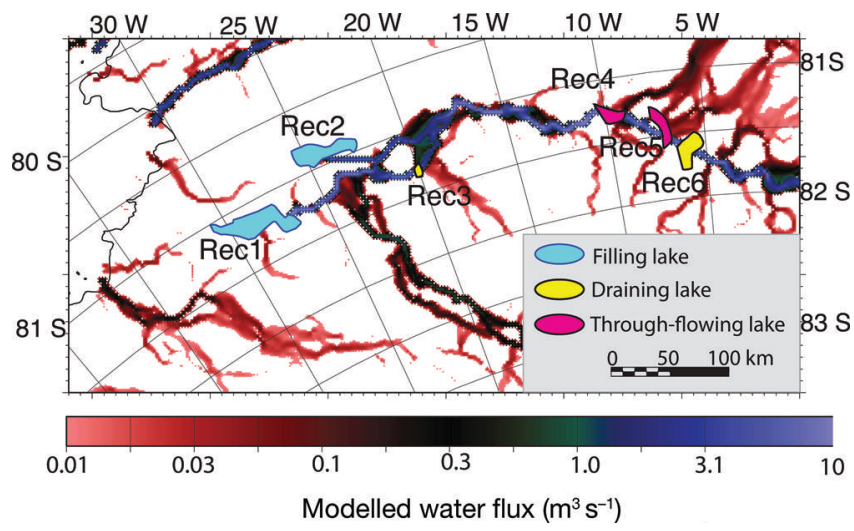

Fig. 7. Snapshot of subglacial water model for one time step showing major flooding event from Rec6 to Rec3 and Rec1; the evolution of the flood for the entire ICESat period 2003-09 is animated in Supplementary Movie S1, online at http://www.igsoc. org/hyperlink/14j063.gif.

not possible due to the lack of data. A snapshot of the model for the period March-June 2006 shows water passing from Rec6 to Rec2 and then Rec1 (Fig. 7). An animation of the model is shown in Supplementary Movie S1 (http://www. igsoc.org/hyperlink/14j063.gif)

Our model results suggest that Rec6 receives water from both Rec 9 and the Rec7/Rec 8 pair. For Rec6 the modelled filling rate is $8.1 \mathrm{~m}^{3} \mathrm{~s}^{-1}$ between November 2003 and March $2005\left(2.7 \mathrm{~m}^{3} \mathrm{~s}^{-1}\right.$ from the drainage of Rec9 and $1.1 \mathrm{~m}^{3} \mathrm{~s}^{-1}$ from lakes Rec7 and Rec8). Given the 25\% uncertainty $\left( \pm 1.6 \mathrm{~m}^{3} \mathrm{~s}^{-1}\right)$ for the observed volume change rate of $6.5 \mathrm{~m}^{3} \mathrm{~s}^{-1}$, we considered the agreement between the modeled results and the observations to be reasonable. The filling and draining cycle of Rec6 regulates lake activity downstream: when Rec6 drains, water fluxes downstream increase by over an order of magnitude.

The estimated volume changes of Rec5 and Rec4 $\left(<10 \mathrm{~m}^{3} \mathrm{~s}^{-1}\right.$ for each), are relatively small compared to that calculated for Rec6 (up to $60 \mathrm{~m}^{3} \mathrm{~s}^{-1}$ ); the estimated volume for these two lakes reached a maximum in 2006/07, approximately coinciding with maximum discharge from Rec6 (Fig. 1, lower left inset). The subsequent rapid subsidence of Rec5 and Rec4 and the low total volume change undergone by these two lakes leads us to propose that these features swell only temporarily during times of high through-flow, instead of acting as substantial water storage features that impound water for a long period. Similar features have been observed on the lower Whillans/ Mercer ice streams (Carter and others, 2013).

Rec3 exhibited even smaller volume changes than Rec5 and Rec4 (estimated $<5 \mathrm{~m}^{3} \mathrm{~s}^{-1}$ ), and it behaved differently to Rec5 and Rec4. There was a small filling event between November 2003 and March 2004, but the model was unable to accurately reproduce the observed filling rate, being too low by a factor of two. Since Rec6 was filling during this period, we could not test for a connection between Rec 3 and Rec6. Between March 2005 and June 2009, when Rec5 and Rec4 were filling and draining (Fig. 1), Rec3 underwent a small draining event, i.e. there was no correlated activity between Rec3 and Rec5-Rec4. This also meant that the only way to treat it in the model during that time was as a source of water. In our model the flow path diverged upstream of Rec3, directing only about half of the water coming from the upstream lakes towards $\operatorname{Rec} 3$, and the rest towards Rec2
(Fig. 7). Combined with the lack of correlated activity between Rec3 and the Rec4-Rec5-Rec6 chain, this leads us to suggest that Rec 3 is not hydrologically connected to those lakes and instead the water that flows into it is more locally derived. Furthermore, it is likely that our assumed uniform melt rate of $0.7 \mathrm{~mm} \mathrm{a}^{-1}$ is too low for Rec3's catchment, given the evidence for enhanced shear heating (Joughin and others, 2006), suggesting that there are higher melt rates immediately upstream.

Rec1 and Rec2 are the only two water bodies downstream of Rec6 with enough storage capacity to truly test whether water is conserved within the system. When the model is tuned to partition equally between a route supplying Rec2 and one bypassing it directly toward Rec1, then the volume for the whole system is conserved, and the model reproduced the observed increase in inflation rate of Rec1 during the drainage of Rec2.

\section{DISCUSSION}

The IceBridge ice thickness data have confirmed a deep subglacial channel (Fig. 3a), first suggested by Joughin and others (2006) from modelling, later inferred by Le Brocq and others (2008) through surface observations, and partially resolved in Bedmap2 data (Fretwell and others, 2013). The channel is almost $1000 \mathrm{~km}$ long and $>2000 \mathrm{~m}$ deep, making it the one of the longest mapped subglacial troughs under either ice sheet, comparable in length to the mega-canyons recently reported in Greenland (Bamber and others, 2013) and the Ellsworth Highlands of Antarctica (Ross and others, 2014). The large subglacial trough contains the main trunk of Recovery Ice Stream, which sits $\sim 1500-2200$ m below sea level. Most of the nine active lakes detected with ICESat data are located at the edges of the subglacial trough. Inversion studies performed by Joughin and others (2006) proposed that beneath Recovery Ice Stream is a large amount of wet, deformable subglacial sediment/till. Although the fact that it sits below sea level would suggest that this ice stream might become sensitive to oceanic forcing, the ridge separating this main trough from the grounding line provides a level of protection that does not appear to exist for neighboring ice streams such as Slessor, Support Force, and Foundation or Möller (Ross and others, 2012). A recent oceanographic modelling study predicted that the area of the Filchner Ice Shelf just in front of Recovery Ice Stream would be susceptible to intrusions of warmer water at the grounding line by $\sim 2075$ (Hellmer and others, 2012). Given the presence of the bedrock ridge between Recovery Ice Stream grounding line and the main ice-stream trunk, its response to thermal oceanic forcing may be markedly different to neighboring ice streams, exhibiting substantially greater stability.

Our lake activity time series derived from ICESat observations for the period 2003-09 (Fig. 1) provides clear evidence that the main Recovery Ice Stream lakes are interconnected, with drainage events in upstream lakes leading to filling events downstream (Smith and others, 2009). The flow paths derived from our subglacial water modelling combined with our data show that for the largest detected drainage event, water was inferred to move $\sim 800 \mathrm{~km}$ from Rec9 to the ocean; this is the longest distance that subglacial water has been inferred to flow under the East Antarctic ice sheet (the next longest being $\sim 290 \mathrm{~km}$ in Adventure Trench (Wingham and others, 2006)). We have 

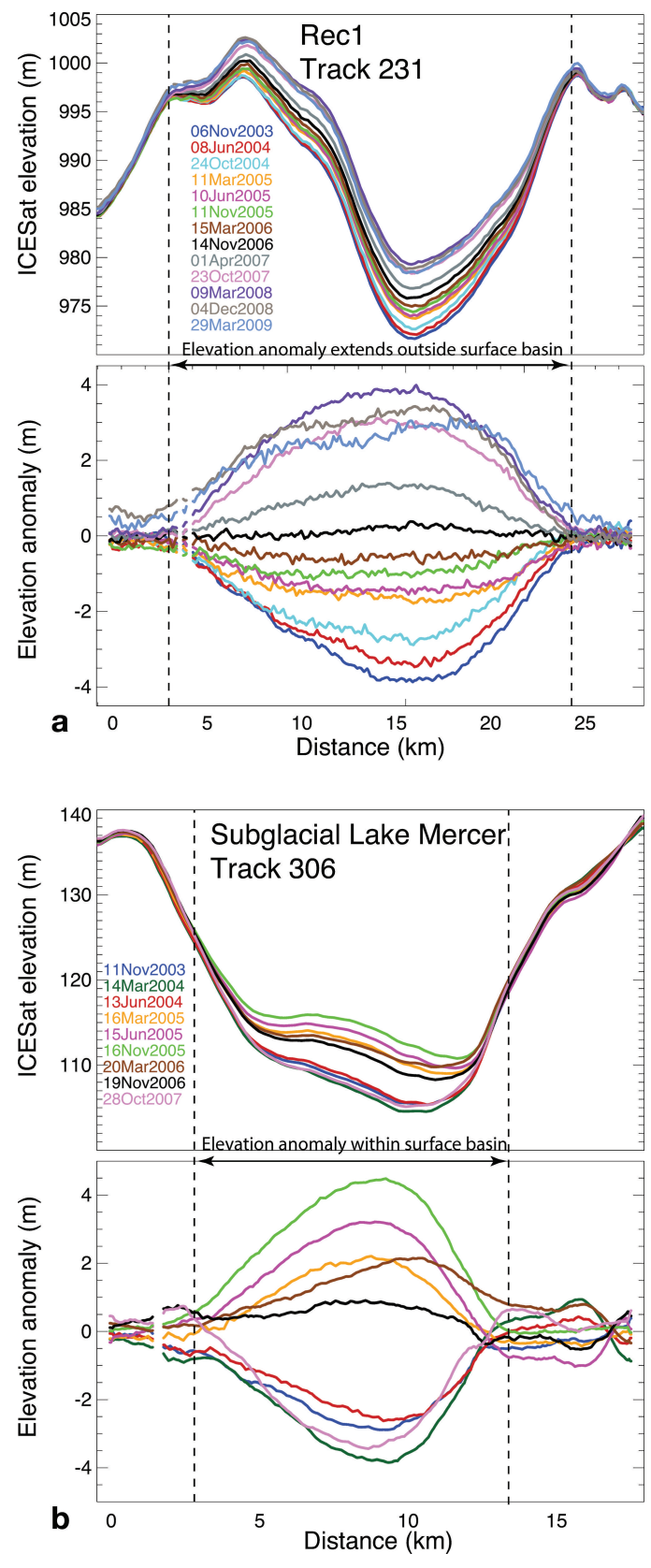

Fig. 8. Typical ICESat elevation anomalies along ICESat tracks that cross subglacial lakes on (a) Recovery Ice Stream and (b) Mercer Ice Stream, showing the different extent of the elevation anomalies with respect to the surface topography. See Figure 1 inset map for location of Mercer Ice Stream in West Antarctica.

shown that the water budget for these lakes balances for the ICESat period 2003-09 and is reproduced by a simple model that assumes $0.7 \mathrm{~mm} \mathrm{a}^{-1}$ melting over the entire glacier catchment. It is also of interest that for two of the lakes in our study (Rec8 and $\operatorname{Rec} 3$ ), the rate of volume loss decreased when a lake upstream was supplying additional water. This would indicate that there is some mechanism that limits the maximum rate of outflow at any given time, further supporting the at least ephemeral presence of conduits (as inferred by Schroeder and others, 2013). Additionally two lakes inflated when through-flow was high, but subsided thereafter, similar to behavior observed at Whillans Ice Stream (Carter and others, 2013). Given this is the second occurrence of such features in a system, it is likely that a number of water bodies included in the Smith and others (2009) inventory may be of a similar nature. Other water systems may become more hydrologically balanced once such features are better accounted for.

The scale of the Recovery hydrologic system is comparable to that of the Whillans/Mercer subglacial water system. However, the elevation anomalies observed over the Recovery lakes are qualitatively different to those observed over the Whillans/Mercer lakes (Fricker and others, 2007; Fricker and Scambos, 2009). On the lower Whillans/Mercer, the elevation anomalies are confined to the bottom of surface topographic basins (Fig. 8), which implies that the water movement is controlled by surface elevation. The lower Whillans/Mercer region is an ice plain that is hydrologically flat with a slope of 0.0001 ; this hydrologic flatness makes the Whillans Ice Plain akin to a river delta. It has been shown that small changes in surface elevation can change the hydrologic potential and lead to complete reorganization of the Whillans subglacial water system through flow switching (Carter and others, 2013). On Recovery Ice Stream, however, bed elevation gradients often exceed surface elevation gradients by more than the critical factor of $\sim 11$. ICESat elevation anomalies extend across the entire topographic basin, including the sides, and then up to several $\mathrm{km}$ outside the basins (Fig. 8). This suggests that the hydropotential is more controlled by the deep bedrock basin in which the glacier sits, and less by surface topography relative to the Whillans systems. Because the bedrock is dominant in controlling the subglacial flow in this case, we propose that the Recovery Ice Stream subglacial system is more stable than the Whillans/ Mercer system. This implies that a much greater change in ice thickness would be required before any major change in water-flow routing could take place in the Recovery system (as described in Carter and others (2013) for the Whillans/ Mercer system). This, combined with the present-day grounding of Recovery Ice Stream at the bottom of the Crary Trough, implies that the ice geometry and subglacial water system have changed only gradually over the past several centuries (as compared to some of the relatively abrupt changes inferred for the Siple Coast (e.g. Hulbe and Fahnestock, 2007)).

Our results point to a strong need for long (preferably decadal), continuous time series if we hope to understand lake activity and evolution for complex subglacial systems. Activity observed during the ICESat mission (2003-09), which is short compared to typical lake cycles, is not necessarily representative of longer-term behavior (Siegfried and others, 2014). For example, Rec3 underwent very little activity over the ICESat period, yet experienced a very large negative elevation change between 2009 and 2011. It has been shown that it is possible to extend the time series using CryoSat-2 data (Siegfried and others, 2014); however, in the Recovery Ice Stream region the synthetic aperture radar interferometric (SARIn) mode mask ends at Rec1, i.e. there are no SARIn mode data over the main Recovery Ice Stream lakes. The low-resolution mode (LRM) is a conventional radar altimeter akin to Envisat's RA-2, and we have demonstrated on MacAyeal Ice Stream that this instrument cannot retrieve accurate data over subglacial lakes on ice streams due to the topography that is rough at length scales on the order of the altimeter pulse-limited footprint (Fricker and others, 2010).

An outstanding question is whether subglacial lakes affect ice dynamics. Water and wet sediments play an important 
role in determining the rate of ice-stream flow and in triggering changes in flow rates over short timescales (Hulbe and Fahnestock, 2007; Peters and others, 2007; Vaughan and Arthern, 2007). So far, there has been only one reported link between a subglacial flood and a glacier speed-up event, on Byrd Glacier (Stearns and others, 2008), although this is likely due to a lack of velocity data coincident with the surface elevation change data. A recent map of difference in ice velocity between two epochs (2009 and 1997; Scheuchl and others, 2012) suggests that the 2009 ice velocity is lower than the 1997 velocity for the entire trunk of Recovery Ice Stream, by slightly more than the regional uncertainties of $8.5 \mathrm{ma}^{-1}$. The only location where there is accelerated flow is directly downstream of Rec1, which was also beginning to drain in 2009 (Fig. 4). This acceleration is consistent with recent work by Kingslake and Ng (2013), which shows that maximum sliding will occur when the lake is near maximum due to outflow being dominated by distributed rather than channelized flow. The widespread deceleration elsewhere in the Recovery Ice Stream catchment suggests that the presence of active lakes does not accelerate flow in the longer term. If water is conserved over long timescales, as appears to be the case in this and in other systems (e.g. Carter and others, 2011; Carter and Fricker 2012), then for every episode of acceleration in response to lake drainage there is also a period during which the lake is filling when the availability of water for lubrication downstream is limited. Consequently the long-term effect of the lake filling and drainage may be to make the ice flow slower than it would be if the lakes drained continuously at the same rate at which they filled.

In order to understand the relationship between subglacial lake dynamics and ice-sheet evolution we require a model for lake volume change and water pressure evolution. If slowdown of the ice propagates upstream in response to changes at the grounding line, then there would be more pronounced thickening in the downstream regions, which would act to decrease the local surface slope (and therefore hydrologic gradient). Although it is possible that the opposite is true, i.e. the gradient increases due to thinning downstream (e.g. by a slow surge which would induce local minima in the ice surface and basal hydropotential), we see no evidence of this having occurred in the recent past in the lowest part of Recovery Ice Stream. We note that Whillans Ice Stream is slowing down at present, and thickening (Pritchard and others, 2009; Beem and others, 2014), and that many of the lake clusters reported by Smith and others (2009) appear to coincide with regions of slowdown and thickening.

Monitoring subglacial outflows from the ice-sheet margins is important for quantifying freshwater flux to the ocean and understanding ice/ocean interactions (Carter and Fricker, 2012). This is a component of mass balance from the ice sheet that has yet to be quantified, and is unlikely to be changing greatly - therefore impacting the other components (albeit only slightly) of the ice-sheet mass budget. For Recovery Ice Stream, the location of subglacial water outflow predicted by our hydropotential map is $>100 \mathrm{~km}$ north of the location of main ice-flux discharge across the grounding line. This suggests that discharge of subglacial water into the cavity, which is hypothesized to affect ice-shelf evolution and stability (e.g. Jenkins, 2011; Carter and Fricker, 2012; Le Brocq and others, 2013), may be less connected to the present-day evolution of Recovery Ice Stream at the grounding zone, relative to locations such as the Siple Coast. Any effect of subglacial outflow on the ice shelf is expected to be highly localized.

\section{SUMMARY}

We have used surface elevation data from IceBridge and ICESat data and ice thickness from IceBridge to reveal information about the Recovery Ice Stream topography and subglacial hydrology. We have shown that there is a deep, long subglacial trough under Recovery Ice Stream in which the main trunk is located: this is one of the largest mapped subglacial troughs under the Antarctic ice sheet. The hydrologic potential that governs the flow of subglacial water within the system is predominately controlled by the bedrock topography; therefore, small changes to the ice thickness cannot alter the hydropotential. This is in contrast to lakes under Whillans/Mercer ice streams where the bedrock is relatively flat and the hydrologic potential is controlled by the surface topography, and is more sensitive to local changes in ice thickness. This implies that the water system under Recovery Ice Stream has likely been stable for centuries and has not undergone any major flow-switching, as has been inferred on Whillans Ice Stream (Carter and others, 2013).

The nine active lakes under the main Recovery Ice Stream trunk are hydrologically connected. The water budget for lakes balances for the ICESat period 2003-09 is dominated by the three largest lakes, and is reproduced by a simple model that assumes $0.7 \mathrm{~mm} \mathrm{a}^{-1}$ melting over the entire glacier catchment, a value consistent with long spatially averaged melt rates throughout many large Antarctic catchments (Joughin and others, 2003; Carter and others, 2009b; Carter and Fricker, 2012). The system appears to require no input from the large lakes (A-D) at the uppermost Recovery Ice Stream region. Two of the lakes (Rec4 and Rec5) appear to be transient reservoirs with little long-term storage of water.

Our results demonstrate the importance of continuous, long-term monitoring of active subglacial lakes. Since subglacial lake activity is episodic, with some of the lakes in the system having periodicities on the order of a decade, to fully understand it we need a long time series of continuous monitoring, along the same ground tracks. Of the three lakes sampled by both ICESat (in 2003-09) and IceBridge (in 2011), there was one that changed continuously throughout the ICESat mission, followed by no change between 2009 and 2011, and then a surface lowering between 2011 and 2012, one that had no significant signal over that time, and another that showed only small change during ICESat and then subsided $10 \mathrm{~m}$ between 2009 and 2011. This highlights the variability of this lake system on short timescales, despite its inferred spatial stability. Because we only have limited satellite-altimeter observations of lake activity (2003-12), we have an incomplete picture of the Antarctic ice sheet's subglacial hydrology; future observations of lake activity will come from CryoSat-2 (McMillan and others, 2013; Siegfried and others, 2014) and ICESat-2.

\section{ACKNOWLEDGEMENTS}

We thank NASA's ICESat Project for distribution of the ICESat data (see http://icesat.gsfc.nasa.gov and http://nsidc.org/data/ icesat) and NASA's Operation IceBridge Project for the airborne laser altimeter and RES data (see http://icebridge. gsfc.nasa.gov and http://nsidc.org/data/icebridge/. We are 
grateful to the Scientific Editor Neil Glasser and two anonymous reviewers who provided constructive comments that significantly improved the manuscript. We thank Matthew Siegfried and Oliver Marsh for proofreading the manuscript and making helpful suggestions. This work was funded by three NASA awards: NNX12AH16G to H.A.F. to support H.A.F. and S.P.C., NNX11AC22G to R.E.B., and NNX10AG21G to T.A.S.

\section{REFERENCES}

Allen C (2010) IceBridge MCoRDS L2 ice thickness [2011-2012] (updated 2014). NASA Distributed Active Archive Center, National Snow and Ice Data Center, Boulder, CO. Digital media: http://nsidc.org/data/irmcr2

Bamber JL, Siegert MJ, Griggs JA, Marshall SJ and Spada G (2013) Paleofluvial mega-canyon beneath the central Greenland ice sheet. Science, 341(6149), 997-999 (doi: 10.1126/science. 1239794)

Beem LH, Tulaczyk SM, King MA, Bougamont M, Fricker HA and Christoffersen P (2014) Variable deceleration of Whillans Ice Stream, West Antarctica. J. Geophys. Res., 119(F2), 212-224 (doi: 10.1002/2013JF002958)

Bell RE, Studinger M, Shuman CA, Fahnestock MA and Joughin I (2007) Large subglacial lakes in East Antarctica at the onset of fast-flowing ice streams. Nature, 445(7130), 904-907 (doi: 10.1038/nature05554)

Bell RE and 11 others (2011) Widespread persistent thickening of the East Antarctic Ice Sheet by freezing from the base. Science, 331(6024), 1592-1595 (doi: 10.1126/science.1200109)

Bindschadler RA, Scambos TA, Choi H and Haran TM (2010) Ice sheet change detection by satellite image differencing. Remote Sens. Environ., 114(7), 1353-1362 (doi: 10.1016/j.rse. 2010.01.014)

Borsa AA, Moholdt G, Fricker HA and Brunt KM (2014) A range correction for ICESat and its potential impact on ice-sheet mass balance studies. Cryosphere, 8(2), 345-357 (doi: 10.5194/tc-8345-2014)

Carter SP, Blankenship DD, Young DA, Peters ME, Holt JW and Siegert MJ (2009a) Dynamic distributed drainage implied by the flow evolution of the 1996-1998 Adventure Trench subglacial lake discharge. Earth Planet. Sci. Lett., 283(1-4), 24-37 (doi: 10.1016/j.epsl.2009.03.019)

Carter SP, Blankenship DD, Young DA and Holt JW (2009b) Using radar-sounding data to identify the distribution and sources of subglacial water: application to Dome C, East Antarctica. J. Glaciol., 55(194), 1025-1040 (doi: 10.3189/ 002214309790794931)

Carter SP and 6 others (2011) Modeling 5 years of subglacial lake activity in the MacAyeal Ice Stream (Antarctica) catchment through assimilation of ICESat laser altimetry. J. Glaciol., 57(206), 1098-1112 (doi: 10.3189/002214311798843421)

Carter SP and Fricker HA (2012) The supply of subglacial meltwater to the grounding line of the Siple Coast, West Antarctica. Ann. Glaciol., 53(60 Pt 2), 267-280 (doi: 10.3189/2012AoG60A119)

Carter SP, Fricker HA and Siegfried MR (2013) Evidence of rapid subglacial water piracy under Whillans Ice Stream, West Antarctica. J. Glaciol., 59(218), 1147-1162 (doi: 10.3189/ 2013JoG13J085)

Creyts TT and Schoof CG (2009) Drainage through subglacial water sheets. J. Geophys. Res., 114(F4), F04008 (doi: 10.1029/ 2008JF001215)

Dupain-Triel, JL (1791) La France considérée dans les différentes hauteurs de ses plaines: ouvrage spécialement destiné à l'instruction de la jeunesse. (BN, Cartes et Plans, map No. Ge. D.15126) Hérault, Paris

Engelhardt H and Kamb B (1997) Basal hydraulic system of a West Antarctic ice stream: constraints from borehole observations. J. Glaciol., 43(144), 207-230
Evatt GW, Fowler AC, Clark CD and Hulton NRJ (2006) Subglacial floods beneath ice sheets. Philos. Trans. R. Soc. London, Ser. A, 364(1844), 1769-1794 (doi: 10.1098/rsta.2006.1798)

Faure G and Mensing TM (2010) The Transantarctic Mountains: rocks, ice, meteorites and water. Springer, Dordrecht

Flament T, Berthier E and Rémy F (2014) Cascading water underneath Wilkes Land, East Antarctic Ice Sheet, observed using altimetry and digital elevation models. Cryosphere, 8(2), 673-687 (doi: 10.5194/tc-8-673-2014)

Flowers GE and Clarke GKC (2002) A multicomponent coupled model of glacier hydrology: 1 . Theory and synthetic examples. J. Geophys. Res., 107(B11), 2287 (doi: 10.1029/2001JB001122)

Fowler AC (2009) Dynamics of subglacial floods. Proc. R. Soc. London, Ser. A, 465(2106), 1809-1828 (doi: 10.1098/ rspa.2008.0488)

Fretwell P and 59 others (2013) Bedmap2: improved ice bed, surface and thickness datasets for Antarctica. Cryosphere, 7(1), 375-393 (doi: 10.5194/tc-7-375-2013)

Fricker HA and Scambos T (2009) Connected subglacial lake activity on lower Mercer and Whillans Ice Streams, West Antarctica, 2003-2008. J. Glaciol., 55(190), 303-315 (doi: 10.3189/002214309788608813)

Fricker HA, Scambos T, Bindschadler R and Padman L (2007) An active subglacial water system in West Antarctica mapped from space. Science, 315(5818), 1544-1548 (doi: 10.1126/ science.1136897)

Fricker HA, Scambos T, Carter S, Davis C, Haran T and Joughin I (2010) Synthesizing multiple remote-sensing techniques for subglacial hydrologic mapping: application to a lake system beneath MacAyeal Ice Stream, West Antarctica. J. Glaciol., 56(196), 187-199 (doi: 10.3189/002214310791968557)

Goodwin ID (1988) The nature and origin of a jökulhlaup near Casey Station, Antarctica. J. Glaciol., 34(116), 95-101

Gray L, Joughin I, Tulaczyk S, Spikes VB, Bindschadler R and Jezek K (2005) Evidence for subglacial water transport in the West Antarctic Ice Sheet through three-dimensional satellite radar interferometry. Geophys. Res. Lett., 32(3), L03501 (doi: 10.1029/2004GL021387)

Haran T, Bohlander J, Scambos T and Fahnestock M (2005) MODIS mosaic of Antarctica (MOA 2009) image map (updated 2014). National Snow and Ice Data Center, Boulder, CO. Digital media: http://nsidc.org/data/moa/

Hellmer H, Kauker F, Timmermann R, Determann J and Rae J (2012) Twenty-first-century warming of a large Antarctic iceshelf cavity by a redirected coastal current. Nature, 485(7397), 225-228 (doi: 10.1038/nature11064)

Hulbe C and Fahnestock M (2007) Century-scale discharge stagnation and reactivation of the Ross ice streams, West Antarctica. J. Geophys. Res., 112(F3), F03S27 (doi: 10.1029/ 2006JF000603)

Jenkins A (2011) Convection-driven melting near the grounding lines of ice shelves and tidewater glaciers. J. Phys. Oceanogr., 41(12), 2279-2294 (doi: 10.1175/JPO-D-11-03.1)

Jezek KC, Farness K, Carande R, Wu X and Labelle-Hamer N (2003) RADARSAT 1 synthetic aperture radar observations of Antarctica: Modified Antarctic Mapping Mission, 2000. Radio Sci., 38(4), 8067 (doi: 10.1029/2002RS002643)

Joughin I and Bamber JL (2005) Thickening of the ice stream catchments feeding the Filchner-Ronne Ice Shelf, Antarctica. Geophys. Res. Lett., 32(17), L17503 (doi: 10.1029/ 2005GL023844)

Joughin IR, Tulaczyk S and Engelhardt HF (2003) Basal melt beneath Whillans Ice Stream and Ice Streams A and C, West Antarctica. Ann. Glaciol., 36, 257-262 (doi: 10.3189/ 172756403781816130)

Joughin I, Bamber JL, Scambos T, Tulaczyk S, Fahnestock M and MacAyeal DR (2006) Integrating satellite observations with modelling: basal shear stress of the Filcher-Ronne ice streams, Antarctica. Philos. Trans. R. Soc. London, Ser. A, 364(1844), 1795-1814 (doi: 10.1098/rsta.2006.1799) 
Kamb B (1987) Glacier surge mechanism based on linked cavity configuration of the basal water conduit system. J. Geophys. Res., 92(B9), 9083-9100 (doi: 10.1029/JB092iB09p09083)

Kingslake J and Ng F (2013) Modelling the coupling of flood discharge with glacier flow during jökulhlaups. Ann. Glaciol., 54(63 Pt 1), 25-31 (doi: 10.3189/2013AoG63A331)

Krabill WB (2014) IceBridge ATM L2 Icessn elevation, slope, and roughness, Version 2 (updated 2014). NASA Distributed Active Archive Center, National Snow and Ice Data Center, Boulder, CO. Digital media: http://nsidc.org/data/ilatm2

Langley K and 8 others (2011) Recovery Lakes, East Antarctica: radar assessment of sub-glacial water extent. Geophys. Res. Lett., 38(5), L05501 (doi: 10.1029/2010GL046094)

Le Brocq AM, Hubbard A, Bentley MJ and Bamber JL (2008) Subglacial topography inferred from ice surface terrain analysis reveals a large un-surveyed basin below sea level in East Antarctica. Geophys. Res. Lett., 35(16), L16503 (doi: 10.1029/ 2008GL034728)

Le Brocq AM and 10 others (2013) Evidence from ice shelves for channelized meltwater flow beneath the Antarctic Ice Sheet. Nature Geosci., 6(11), 945-948 (doi: 10.1038/ngeo1977)

McMillan M, Corr H, Shepherd A, Ridout A, Laxon S and Cullen R (2013) Three-dimensional mapping by CryoSat-2 of subglacial lake volume changes. Geophys. Res. Lett., 40(16), 4321-4327 (doi: 10.1002/grl.50689)

Parizek BR, Alley RB and Hulbe CL (2003) Subglacial thermal balance permits ongoing grounding-line retreat along the Siple Coast of West Antarctica. Ann. Glaciol., 36, 251-256 (doi: 10.3189/172756403781816167)

Peters LE, Anandakrishnan S, Alley RB and Smith AM (2007) Extensive storage of basal meltwater in the onset region of a major West Antarctic ice stream. Geology, 35(3), 251-254 (doi: 10.1007/s003820050271)

Pritchard HD, Arthern RJ, Vaughan DG and Edwards LA (2009) Extensive dynamic thinning on the margins of the Greenland and Antarctic ice sheets. Nature, 461(7266), 971-975 (doi: 10.1038/nature08471)

Quinn PF, Ostendorf B, Beven K and Tenhunen J (1998) Spatial and temporal predictions of soil moisture patterns and evaporative losses using TOPMODEL and the GASFLUX model for an Alaskan catchment. Hydrol. Earth Syst. Sci., 2(1), 51-64 (doi: 10.5194/hess-2-51-1998)

Rignot E, Mouginot J and Scheuchl B (2011) Ice flow of the Antarctic Ice Sheet. Science, 333(6048), 1427-1430 (doi: 10.1126/science.1208336)

Ross N and 9 others (2012) Steep reverse bed slope at the grounding line of the Weddell Sea sector in West Antarctica. Nature Geosci., 5(6), 393-396 (doi: 10.1038/ngeo1468)

Ross $\mathrm{N}$ and 8 others (2014) The Ellsworth Subglacial Highlands: inception and retreat of the West Antarctic Ice Sheet. Geol. Soc. Am. Bull., 126(1-2), 3-15 (doi: 10.1130/B30794.1)

Saunders W (2000) Preparation of DEMs for use in environmental modeling analysis. In Maidment D and Djokic D eds. Hydrologic and hydraulic modeling support with Geographic Information Systems. Environmental Systems Research Institute, Redlands, CA

Scambos TA, Haran TM, Fahnestock MA, Painter TH and Bohlander J (2007) MODIS-based Mosaic of Antarctica (MOA) data sets: continent-wide surface morphology and snow grain size. Remote Sens. Environ., 111(2-3), 242-257 (doi: 10.1016/j. rse.2006.12.020)

Scambos TA, Berthier E and Shuman CA (2011) The triggering of subglacial lake drainage during rapid glacier drawdown: Crane Glacier, Antarctic Peninsula. Ann. Glaciol., 52(59), 74-82 (doi: 10.3189/172756411799096204)

Scheuchl B, Mouginot J and Rignot E (2012) Ice velocity changes in the Ross and Ronne sectors observed using satellite radar data from 1997 and 2009. Cryosphere, 6(5), 1019-1030 (doi: 10.5194/tc-6-1019-2012)

Schroeder DM, Blankenship DD and Young DA (2013) Evidence for a water system transition beneath Thwaites Glacier, West
Antarctica. Proc. Natl Acad. Sci. USA (PNAS), 110(30), 12 225-12 228 (doi: 10.1073/pnas.1302828110)

Shreve RL (1972) Movement of water in glaciers. J. Glaciol., 11(62), 205-214

Siegert MJ, Carter S, Tabacco I, Popov S and Blankenship DD (2005) A revised inventory of Antarctic subglacial lakes. Antarct. Sci., 17(3), 453-460 (doi: 10.1017/S0954102005002889)

Siegert MJ and 8 others (2014) Boundary conditions of an active West Antarctic subglacial lake: implications for storage of water beneath the ice sheet. Cryosphere, 8(1), 15-24 (doi: 10.5194/ tc-8-15-2014)

Siegfried MR, Fricker HA, Roberts M, Scambos TA and Tulaczyk S (2014) A decade of West Antarctic subglacial lake interactions from combined ICESat and CryoSat-2 altimetry. Geophys. Res. Lett., 41(3), 891-898 (doi: 10.1002/2013GL058616)

Smith BE, Fricker HA, Joughin IR and Tulaczyk S (2009) An inventory of active subglacial lakes in Antarctica detected by ICESat (2003-2008). J. Glaciol., 55(192), 573-595 (doi: 10.3189/002214309789470879)

Stearns LA, Smith BE and Hamilton GS (2008) Increased flow speed on a large East Antarctic outlet glacier caused by subglacial floods. Nature Geosci., 1(8), 827-831 (doi: 10.1038/ngeo356)

Swithinbank C, Brunk K and Sievers H (1998), A glaciological map of Filchner-Ronne Ice Shelf, Antarctica. Ann. Glaciol., 11, 150-155

Vaughan DG and Arthern R (2007) Why is it hard to predict the future of ice sheets? Science, 315(5818), 1503-1504 (doi: 10.1126/science.1141111)

Wingham DJ, Siegert MJ, Shepherd A and Muir AS (2006) Rapid discharge connects Antarctic subglacial lakes. Nature, 440(7087), 1033-1036 (doi: 10.1038/nature04660)

Wolovick MJ, Bell RE, Creyts TT and Frearson N (2013) Identification and control of subglacial water networks under Dome A, Antarctica. J. Geophys. Res., 118(1), 140-154 (doi: 10.1029/2012JF002555)

Wright A and Siegert M (2012) A fourth inventory of Antarctic subglacial lakes. Antarct. Sci., 24(6), 659-664 (doi: 10.1017/ S095410201200048X)

Wright AP, Siegert MJ, Le Brocq AM and Gore DB (2008) High sensitivity of subglacial hydrological pathways in Antarctica to small ice-sheet changes. Geophys. Res. Lett., 35(17), L17504 (doi: 10.1029/2008GL034937)

Wright AP and 12 others (2012) Evidence of a hydrological connection between the ice divide and ice sheet margin in the Aurora Subglacial Basin, East Antarctica. J. Geophys. Res., 117(F1), F01033 (doi: 10.1029/2011JF002066)

\section{APPENDIX A: DEVELOPING THE HYDROLOGIC POTENTIAL GRID AND THE FLOW PATHS}

After obtaining the initial hydropotential surface described in Section 3 we traced several prominent drainages by following a contour map of the initial hydrologic potential using the ancient method of Dupain-Triel (1791), locating the intersection between these drainages and local minima in the hydrologic potential along every RES profile. We used a piecewise cubic hermitic polynomial to interpolate the geometry of the drainage path between these intersection points. The hydrologic potential of cells containing portions of this stream was set to the hydrologic potential of the points along the drainage path rather than averaging all measurements within the cell. This effectively etched a stream path into the hydrologic potential grid (Saunders, 2000).

Given the general sparseness of data, uncertainties in input data (e.g. Siegert and others, 2014) and the sensitivity of water routing to changes of $<5 \mathrm{mw}$.e. in the hydropotential (e.g. Wright and others, 2008; Carter and others, 2013) we made some adjustments to the initial hydropotential surface. After running the model with the initial 
hydropotential surface, we compare our modelled water distribution against the lake location and hydropotential map to identify where realistic adjustments to the relative bed topography might redirect more or less water toward a given lake. Every effort is made to ensure that such adjustments are within the error limit of the ice thickness measurements, with larger adjustments allowed in areas where the bed topography is less well constrained. The model is rerun to calculate the impact of the adjustment on the target lake and lakes downstream, until modelled inflow for each lake is as close to observed inflation rates as could reasonably be accommodated. Around Rec7, Rec8 and Rec9, substantial adjustments were necessary. This is not surprising as the bed topography in this region was based on inversion of satellite-based gravity measurements (Fretwell and others, 2013), a technique incapable of resolving bedrock features on the order of $5 \mathrm{~km}$ as would be needed to attain accurate flow paths in this region. Additional adjustment was required in the vicinity of Rec2, where what appears to have been some of the deepest topography was often not resolved due to scattering from surface crevasses, basal ice that is likely quite warm and attenuative, and the limited ability of IceBridge MCoRDS to resolve steep escarpments at depths exceeding $2 \mathrm{~km}$. We further justify the tuning in this region by noting that the IceBridge data appear to indicate a local maximum in the hydropotential running down the axis of this trench.

\section{APPENDIX B: SUBGLACIAL WATER MODEL}

The model directs subglacial meltwater down the hydrologic potential and calculates the change in water distribution from the storage and release of water by previously documented subglacial lakes (Fig. 3). Our model does not address the physical mechanisms of flood initiation and termination (e.g. Evatt and others, 2006; Fowler, 2009), nor does it attempt to identify a particular flow mechanism (i.e. focused conduits vs distributed sheets or cavities; e.g. Flowers and Clarke, 2002; Creyts and Schoof, 2009). It simply tests whether the hydrologic potential surface, basal melt distribution, and lake volume change are consistent with each other. Once this is established, we confirm hydrologic connections between the various subglacial lakes in our domain and infer water sources for each of the lakes. To improve the model's water routing we have increased the spatial resolution from $5 \mathrm{~km} \times 5 \mathrm{~km}$ to $2.5 \mathrm{~km} \times 2.5 \mathrm{~km}$.

Water is routed via a simple 'steady-state D8' (Quinn and others, 1998) in which flux out of a cell is equal to the sum of incoming flux and local melt.

$$
Q_{\text {out }}=Q_{\text {in }}+\dot{m} \Delta x \Delta y
$$

where $Q_{\text {in }}$ and $Q_{\text {out }}$ are water flux in and out of a cell, respectively, $\dot{m}$ is the basal melt rate (negative, if water is freezing to the base), and $\Delta x$ and $\Delta y$ are the cell's horizontal dimensions. Qout is apportioned to each of the 'downstream' cells (subscript ' $i$ ' referring the adjacent downstream cell in question), calculating $Q_{i}$ using

$$
Q_{i}=Q_{\text {out }} \frac{\frac{\mathrm{d} \phi}{\mathrm{d} s_{i}}}{\sum_{n=1}^{k} \frac{\mathrm{d} \phi}{\mathrm{d} s}}
$$

with $k$ being the number of adjacent cells with lower hydrologic potential, $\mathrm{d} \phi$ the hydropotential loss of the adjacent cell and $\mathrm{d} s$ the distance to the adjacent cell $(\Delta x$, $\Delta y$ or $\sqrt{\Delta x^{2}+\Delta y^{2}}$ ) such that more flow goes toward adjacent cells with steeper downward gradients.

For cells lying within subglacial lakes, we apply additional forcing depending on whether a lake was inferred to be filling or draining during each time interval (3-4 months, defined by the timing of the ICESat campaigns; see Section 3). For intervals when a lake was inferred to be filling, the corresponding cells are treated as hydrologic sinks, setting $Q_{\text {out }}$ to zero. We then compare the flux of water into the lake predicted by the model against the observed volume increase. When lake volumes are decreasing, we add the inferred volume loss to the melt rate for cells within this lake and allow water flowing in from upstream to pass through as described in Eqns (B1) and (B2). In summary, observations of lake volume increases are used to validate our model while observations of lake volume decreases are used to force it. 